\title{
Pancreatic Cancer Small Extracellular Vesicles (Exosomes): A Tale of Short- and Long-Distance Communication
}

\author{
Mareike Waldenmaier, Tanja Seibold (), Thomas Seufferlein ${ }^{\dagger}$ and Tim Eiseler ${ }^{*},+$ \\ Department for Internal Medicine, University Clinic Ulm, 89081 Ulm, Germany; \\ mareike.waldenmaier@uniklinik-ulm.de (M.W.); tanja.seibold@uniklinik-ulm.de (T.S.); \\ thomas.seufferlein@uniklinik-ulm.de (T.S.) \\ * Correspondence: tim.eiseler@uniklinik-ulm.de; Tel.: +49-73150044661 \\ + Shared senior authors.
}

Simple Summary: Even today, pancreatic cancer still has a dismal prognosis. It is characterized by a lack of early symptoms and thus late diagnosis as well as early metastasis. The majority of patients suffer from pancreatic ductal adenocarcinoma (PDAC). PDACs communicate extensively with cellular components of their microenvironment, but also with distant metastatic niches to facilitate tumor progression and dissemination. This crosstalk is substantially enabled by small extracellular vesicles (sEVs, exosomes) with a size of 30-150 nm that are released from the tumor cells. sEVs carry bioactive cargos that reprogram target cells to promote tumor growth, migration, metastasis, immune evasion, or chemotherapy resistance. Interestingly, sEVs also carry novel diagnostic, prognostic and potentially also predictive biomarkers. Moreover, engineered sEVs may be utilized as therapeutic agents, improving treatment options. The role of sEVs for PDAC development, progression, diagnosis, prognosis, and treatment is the focus of this review.

Citation: Waldenmaier, M.; Seibold, T.; Seufferlein, T.; Eiseler, T. Pancreatic Cancer Small Extracellular Vesicles (Exosomes): A Tale of Short- and Long-Distance Communication. Cancers 2021, 13, 4844. https:// doi.org/10.3390/cancers13194844

Academic Editor: Eva

Diamantis Karamitopoulou

Received: 30 August 2021

Accepted: 24 September 2021

Published: 28 September 2021

Publisher's Note: MDPI stays neutral with regard to jurisdictional claims in published maps and institutional affiliations.

Copyright: (c) 2021 by the authors. Licensee MDPI, Basel, Switzerland. This article is an open access article distributed under the terms and conditions of the Creative Commons Attribution (CC BY) license (https:/ / creativecommons.org/licenses/by/ $4.0 /)$.
Abstract: Even with all recent advances in cancer therapy, pancreatic cancer still has a dismal 5-year survival rate of less than $7 \%$. The most prevalent tumor subtype is pancreatic ductal adenocarcinoma (PDAC). PDACs display an extensive crosstalk with their tumor microenvironment (TME), e.g., pancreatic stellate cells, but also immune cells to regulate tumor growth, immune evasion, and metastasis. In addition to crosstalk in the local TME, PDACs were shown to induce the formation of pre-metastatic niches in different organs. Recent advances have attributed many of these interactions to intercellular communication by small extracellular vesicles (sEVs, exosomes). These nanovesicles are derived of endo-lysosomal structures (multivesicular bodies) with a size range of 30-150 nm. sEVs carry various bioactive cargos, such as proteins, lipids, DNA, mRNA, or miRNAs and act in an autocrine or paracrine fashion to educate recipient cells. In addition to tumor formation, progression, and metastasis, sEVs were described as potent biomarker platforms for diagnosis and prognosis of PDAC. Advances in sEV engineering have further indicated that sEVs might once be used as effective drug carriers. Thus, extensive sEV-based communication and applications as platform for biomarker analysis or vehicles for treatment suggest a major impact of sEVs in future PDAC research.

Keywords: pancreatic cancer; small extracellular vesicle; exosomes; sEVs; tumor growth; immune evasion; metastasis; biomarker; therapeutic sEVs

\section{Pancreatic Cancer and Intercellular Crosstalk}

Pancreatic cancer is a deadly disease with a 5-year overall survival rate of less than $7 \%$ [1]. It is characterized by late diagnosis, due to the lack of early symptoms, a highly fibrotic tumor microenvironment (TME), and early metastasis [2]. The only potentially curative treatment to date is surgical resection [1]. The majority of pancreatic cancer cases ( $\sim 95 \%$ ) belong to the pancreatic ductal adenocarcinoma subtype (PDAC) [3]. PDAC was shown to arise from acinar-to-ductal metaplasia (ADM), induced by pancreatic injury, pancreatitis, or genotoxic events. ADMs can further evolve through acquisition of mutations 
into stages of pancreatic intraepithelial neoplasia (PanINs 1-3) [4]. Genetic abnormalities include early activating mutations in Kirsten rat sarcoma (KRAS) and inactivation of cyclin dependent kinase inhibitor 2A (p16/CDKN2A). Their frequencies increase with dysplasia. Mutations in tumor protein 53 (TP53) and SMAD family member 4 (SMAD4) inactivation are late events observed in PanIN3 lesions, which in the end develop into full-blown PDAC with a highly fibrotic and complex TME [4-6]. The TME comprises cancer-associated fibroblasts (CAFs), pancreatic stellate cells (PSCs), and immune-inhibitory cells, such as immunosuppressive tumor-associated M2-polarized macrophages (M2-TAMs), regulatory T-cells $\left(\mathrm{T}_{\text {regs }}\right)$, or myeloid-derived suppressor cells (MDSCs) [7,8]. Within the TME, tumor cells were shown to communicate with the surrounding stromal cell compartment through the release of secreted factors, but also via extracellular vesicles [9]. In the recent years, in particular small extracellular vesicles (sEVs, exosomes) were described as major mediators of intercellular communication during cancer initiation and progression [10]. In fact, tumor cells do not only communicate with cells in the primary TME, but there is also long-distance communication via circulating sEVs, e.g., during the establishment of pre-metastatic niches (PMNs) [11]. Thus, research into sEV biogenesis and function has evolved as a promising new research field that helps to define novel mechanisms of tumor evolution.

\section{Overview: Small Extracellular Vesicles and Its Predominant Subgroup Exosomes}

The term sEVs specifies a particular subgroup of extracellular vesicles with a diameter of $30-150 \mathrm{~nm}$, which is predominantly made up by the exosome subgroup, although a subpopulation of microvesicles has also been described in the respective size range [12]. This review mainly focuses on the role of exosomes in PDAC. For the sake of easy communication with the reader, we have however attributed biological effects to the broader specification "sEVs", which is often used instead of the term "exosomes" in the literature [13]. sEVs are formed as intraluminal vesicles (ILVs) in endosomal-derived multivesicular bodies (MVBs). Upon transport and fusion of MVBs with the plasma membrane, the intraluminal sEVs are released into the extracellular space [14]. Initially, sEVs were thought to be vehicles for cellular waste removal. However, further research revealed that a major function of sEVs is intercellular communication [15]. sEVs are present in almost all body fluids, i.e., blood, saliva, urine, liquor and many more. In electron microscopy, sEVs mainly present as spherical cup-shaped nanoparticles, engulfed by a phospholipid bilayer [16]. They typically contain numerous bioactive molecules, including proteins, various nucleic acids and lipids as well as inorganic substances, which are locally and systemically transferred to recipient cells [17]. sEVs are generated by different cell types under physiological and pathophysiological conditions that critically shape the respective cargo profile [18]. sEVs share similar structural proteins, such as Rab-GTPases, class 1 and 2 major histocompatibility complexes (MHC I/II), annexins, ALG-2 interacting protein X (ALIX), tumor susceptibility gene 101 protein (TSG101), flotillin (FLOT1), integrins, and in particular tetraspanins (Tspans), which are major surface markers enriched in sEVs $[19,20]$. Tspans belong to a 4-transmembrane protein family, comprising CD9, CD63, CD81, CD82, CD53, and CD37, which are up to a 100 -fold more enriched in sEVs compared to their parental cells [21,22]. Tspans can form homo-and heterodimers, as well as complex secondary and tertiary interactions known as the tetraspanin web. They couple to lipids (e.g., cholesterol) and form tetraspanin-enriched microdomains (TEMs), which help to recycle Tspan binding partners, such as specific integrins or proteases from the cell surface into MVBs and eventually sEVs [23,24]. In addition to TEMs, sEVs also contain caveolae lipid raft microdomains. Both structures help to transduce important signals, such as apoptosis and cell cycle arrest, via lipid molecules or resident proteins [25-27]. Several lipids, such as cholesterol, sphingomyelin, gangliosides, ceramide, phosphatidylserine, and phosphatidylethanolamine, make up the composition of sEV membranes, which can also have important signaling properties dependent on the respective cellular context [28,29]. sEV cargo also contains a broad spectrum of nucleic acids, including messenger (m)RNA and noncoding (nc)RNAs, such as micro (mi)RNA, ribosomal (r)RNA, transfer (t)RNA, long non-coding (lnc)RNA, long intervening non-coding 
(linc)RNA, small nuclear (sn)RNA, small nucleolar (sno)RNA, circular (circ)RNA as well as cell-free cellular (cf)DNA or mitochondrial (mt)DNA [30]. In cancer, sEVs were shown to be highly enriched in miRNAs [31,32]. The sEV proteome comprises signal intermediates, heat shock proteins, such as HSP70/90, as well as epithelial cell adhesion molecules (EpCAM), cell membrane receptors, e.g., EGFR and other human epidermal receptor (HER) family members, immunomodulatory proteins, cytokines, cytoskeletal molecules, and cytosolic components $[20,33]$.

\section{1. sEV-Biogenesis}

sEV-biogenesis starts at the endosomal compartment by maturing early endosomes into late endosomes or MVBs, where membranes invaginate to generate ILVs. The formation of ILVs is facilitated by two major pathways: The endosomal sorting complex required for transport (ESCRT)-dependent and ESCRT-independent pathway. The ESCRT machinery is a large multi-protein complex consisting of four subcomplexes: ESCRT-0, -I, -II, -III as well as the associated AAA-ATPase Vps4, which initiate biogenesis in a coordinated fashion [34]. ESCRT-0 is thought to initiate the pathway by binding to phosphatidylinositol3-phosphate (PI3P) and clustering tagged, ubiquitinated membrane EV cargo proteins. Then ESCRT-I is recruited by ESCRT-0, which also binds to the ubiquitinated cargo, followed by ESCRT-II [35,36]. The ESCRT-II subunit Vps25 subsequently serves as a nucleation hub for the stepwise assembly of a filamentous ESCRT-III complex, which in turn facilitates cargo sequestration and inward budding of the ILV. Afterwards, ESCRT-III also terminates the assembly of the filaments on the endosome surface $[37,38]$. Then, AAA-ATPase Vps4 is recruited and catalyzes the disassembly of the ESCRT-III filaments in an ATPdriven reaction to terminate MVB-biogenesis, followed by the release of the cargo-laden ILV [39]. MVB-biogenesis can also progress without ESCRTs. Tspans and ceramide are involved in ESCRT-independent sEV-biogenesis and -release. Inhibition of neutral sphingomyelinase 2 (nSMase2), an enzyme that generates ceramide from sphingomyelin, by the small molecule GW4869 [18,40-42] has been shown to reduce sEV-release [18,40]. ESCRTdependent and ESCRT-independent mechanisms might also not be entirely separated. Both pathways could work synergistically, and different subpopulations of sEVs may use different machineries. Additionally, cell type or cellular state are important factors determining the type of vesicle biogenesis [43]. Once ILV-biogenesis is complete, MVBs have to be transported along microtubules to the plasma membrane (PM), where ILVs are released upon fusion [44]. This process is controlled by soluble N-ethylmaleimide-sensitive factor attachment protein receptors (SNAREs) and small Rab-GTPases, such as Rab27a/b or Rab11, which regulate different aspects of ESCRT-dependent and -independent sEV release [21]. Moreover, efficient fusion and sEV release from cells requires the presence of branched actin filaments at the PM. Branched actin is stabilized or debranched by the antagonistic action of the actin-regulatory proteins Cortactin and Coronin-1, respectively [45]. Cortactin is also involved in the Arp2/3-complex-dependent synergistic nucleation of branched actin filaments at the PM together with the nucleation promoting factor WAVE2 [46,47]. In PDAC cells, knockdown of WAVE2 and Cortactin critically impaired sEV release. An additional layer of control is added by a posttranslational modification of Cortactin that only contributes to actin-mediated sEV-release when a regulatory phosphorylation by Protein Kinase D (PKD) is abrogated [47,48]. Under more specialized conditions, such as when cancer cells form invadopodia, N-WASP, a different nucleation promoting factor, is required for synergistic nucleation and sEV secretion [45]. Thus, sEV-biogenesis is a highly regulated and coordinated process and secretion as well as final release of different sEV subpopulations can be dependent on different biogenesis pathways.

\section{2. sEV-Uptake and Reprogramming of Recipient Cells}

Upon delivery of sEVs to recipient cells, e.g., by blood flow, sEVs interact with the respective cells in different ways. They can directly bind via surface ligands to membraneintegrated receptors and thus activate specific signaling pathways. Alternatively, sEVs are 
internalized to release their transported cargos, which is facilitated by various mechanisms, including direct membrane fusion, clathrin- or lipid raft (Caveolae/caveolin-1)-mediated endocytosis, micropinocytosis, or phagocytosis. Upon entering a cell, e.g., by endocytosis, late endosomes containing sEVs either fuse with lysosomes to recycle sEVs and their cargos, or release their content into the cytoplasm to trigger signaling pathways or transcriptional changes [21]. There is ample evidence that sEVs have vital functions in carcinogenesis and evolution of PDAC as well as in the pathogenesis of precancerous conditions of the pancreas, including pancreatitis or pancreatic fibrosis [49,50]. Indeed, sEVs were shown to promote the transformation of precancerous lesions, such as PanINs to PDAC. They extensively contribute to intercellular communication between tumor cells and associated cells in the primary TME, facilitate cell migration, epithelial-to-mesenchymal transition (EMT) as well as apoptosis and chemoresistance. In later stages they also impact on PDAC metastasis by inducing the establishment of organ-specific PMNs [50]. Here we focus on the functions and underlying molecular mechanisms that are involved in sEV-mediated PDAC carcinogenesis, tumor progression, and metastasis.

\section{Modulators of sEV-Biogenesis}

PDACs are often associated with elevated SEV secretion, as plasma samples acquired from PDAC patients show enhanced concentrations of circulating sEVs, which are further increased with metastatic burden [51]. Different cellular and molecular stress conditions, such as hypoxia and low $\mathrm{pH}$ can foster formation of sEVs and cause quantitative, but also qualitative changes in the $\mathrm{sEV}$ cargo content. sEVs were therefore described as promising analytes to evaluate the presence of diagnostic and prognostic markers [52,53]. Indeed, hypoxia is also an important characteristic of the PDAC TME and was shown to trigger the release of sEVs with smaller size, which help the tumor to adapt to challenging conditions and enable survival of tumor cells [54]. Moreover, oncogenes facilitate sEV-biogenesis in different cancer entities, altering sEV concentration, size, and cargo [55-60]. They also maintain biomass homeostasis and foster accelerated cell division as well as tumor growth by enhanced sEV-biogenesis. Moreover, oncogenes, such as Harvey rat sarcoma (HRAS), aurora kinase B (AURKB), and MYC were shown to promote aberrant sEV secretion by triggering hyperactivation of ESCRT-pathways, the ceramide metabolism, or by reducing lysosome-associated gene expression, which also shifts the protein and miRNA content of sEVs [55]. In cancer, sEVs are highly enriched in miRNAs [31,32]. There is evidence, that miRNAs influence oncogenic processes by either suppressing or promoting the expression of oncogenes (tumor suppressor miRs or oncomiRs) [61]. The KRAS oncogene drives PDAC carcinogenesis and not only promotes sEV-release, but also alters their cargo composition compared to wild-type KRAS tumors. The mutant KRAS-derived sEVs are characterized by tumor-promoting proteins, including mutant KRAS and p53 as well as an altered miRNA content, enabling oncogenic transfer and metabolic reprogramming in recipient cells [58-60]. Thus, oncogenes modulate sEVs and are horizontally transferred via sEVs to surrounding cells $[51,55,62]$. So far in PDAC, no oncogenes were directly described to boost sEV-biogenesis. Since mutations in KRAS are found in $>90 \%$ of PDACs and mutated KRAS facilitates changes in sEV cargo content in colorectal cancer, similar functions are however very likely $[55,59,63]$.

\section{4. sEVs in Pancreatic Cancer Initiation}

Pancreatitis is considered a risk factor for the development of PDAC. In addition, tobacco smoking, diabetes, obesity, physical inactivity, infections, genetic alterations, and alcohol consumption can contribute to PDAC carcinogenesis [64]. Pancreatitis is classified into acute (AP) or chronic (CP), as well as autoimmune (AIP) pancreatitis, whereby the latter is a type of $\mathrm{CP}$ with very distinct histological and clinical features [65]. In particular $\mathrm{CP}$ carries an increased risk for the development of PDAC [66,67]. Pathology of CP includes exocrine and endocrine pancreatic insufficiency, inflammation as well as high levels of pancreatic fibrosis [68]. There has been increasing evidence that sEVs are also involved 
in inflammatory signaling during pancreatitis or carcinogenesis of PDAC [69]. During $\mathrm{AP}$, the concentration of circulating sEVs is significantly increased. The respective sEVs originate from liver and immune cells and mediate molecular changes associated with irreversible interstitial fibrosis as well as parenchymal pancreatic calcification. Moreover, the respective $s E V s$ pass through the endothelial barrier in lungs and induce M1-polarization of macrophages promoting acute lung injury (ALI) [70]. Interestingly, circulating AP-sEVs also contain proinflammatory miRNAs such as miR-21/122/155 [71]. CP also causes substantial pancreatic tissue destruction as well as exocrine and endocrine insufficiency. It results in the activation of PSCs, inducing their proliferative capacity [72]. PSCs in turn communicate with pre-cancerous PanINs to promote their progression [73,74]. This is mediated by connective tissue growth factor 2 (CCN2/CTGF2). Clinical studies have also demonstrated that CCN2 is highly expressed in PSCs from (alcoholic) CP patients [75]. CCN2 expression is controlled by miR-21 and both CCN2 as well as miR-21 were detected in PSC-derived sEVs. Using an alcoholic pancreatitis mouse model it has been shown that miR-21- and CCN2-positive sEVs educate other PSCs in a paracrine fashion to potentiate proliferation and collagen deposition [76].

\section{5. sEV-Mediated Crosstalk of PDAC and Associated Cells in the TME}

Upon progression through PanIN stages, carcinogenesis is concluded with the development of full PDAC tumors, which shape their surrounding TME by interacting with stromal extracellular matrix (ECM) components and cells, such as stromal fibroblasts or cells of the innate and adaptive immune system [77]. A major hallmark of PDAC is the desmoplastic tumor stroma, which emerges from abundant ECM deposition that can constitute up to $90 \%$ of the tumor mass [2,78]. The TME comprises various cell types, e.g., fibroblasts, mesenchymal cells (MSCs), and immune cells [79]. The non-cellular components include ECM proteins, such as collagen, fibronectin, hyaluronic acid, laminin as well as metabolites, cytokines, and growth factors [80,81]. Autocrine and paracrine interactions between the different cell types and the tumor cells extensively contribute to PDAC tumorigenesis, angiogenesis, metabolic reprogramming, impaired antitumor immune responses, drug resistance, and metastasis [82-84]. Over the last years, sEVs were shown to critically contribute to PDAC carcinogenesis and progression, enabling intercellular crosstalk between the tumor and surrounding cells in the TME, e.g., by triggering the transformation of non-malignant to malignant cells $[82,85]$. A comprehensive overview of the respective sEV cargos involved in PDAC crosstalk with the TME is available in Table 1.

\subsection{PDAC-sEVs and CAFs}

The TME consists of matrix-associated cell types, which utilize sEVs to interact with PDAC tumor cells and vice versa tumor cells were shown to reprogram associated stromal cells, e.g., fibroblasts $[9,50]$. During early tumor initiation, tumor-derived sEVs reprogram PSCs to direct their differentiation into CAFs via TGF $\beta /$ Smad signaling $[85,86]$. Moreover, CAFs can also be generated from normal fibroblasts [87] and represent one of the most prominent and heterogenous components of the TME. They mediate proand antitumorigenic functions but are mainly responsible for the extensive desmoplasia associated with PDAC. Aberrant ECM deposition and remodeling associated with massive desmoplasia further causes hypoxia and blood vessel depletion, triggering alterations in blood supply and thus metabolic adaptation of tumors, which eventually foster PDAC aggressiveness $[80,85,88,89]$. Moreover, oxygen deprivation was demonstrated to promote sEV-biogenesis, as PDAC cells release increased amounts of sEVs with smaller size to ensure survival under such conditions [54]. In addition, hypoxia is associated with changes in sEV cargo content, e.g., by facilitating the secretion of miR-301a-3p-loaded sEVs from PDAC cells. Paracrine transfer of these sEVs to other PDAC cells enhanced tumor cell invasiveness and uptake by macrophages mediated conversion to immunosuppressive M2subtypes [90]. Additionally, PDAC cells were reported to benefit from CAF-derived sEVs under nutrient-stress conditions. Here, CAF-sEVs enhanced the Warburg effect in PDAC 
cells by reprogramming the energy metabolism through direct delivery of de novo metabolites to support the entire carbon metabolism and PDAC survival [91]. Metabolite transfer by sEVs was also shown using ${ }^{13} \mathrm{C}$ metabolic flux analysis to track dynamic changes in cargo release from CAFs and internalization of sEVs by cancer cells over time [92]. Other consequences of hypoxia are reduced sensitivity towards radio- and chemotherapy as well as immunosuppression [89].

\section{2. sEV-Based Crosstalk of PDAC and PSCs}

PSCs mediate vital functions during pancreatic fibrosis [93]. Their interaction with tumor cells and stromal cell components enhances cell growth and distant metastasis [94]. PSCs usually exist in a quiescent state and maintain normal stromal composition (ECM turnover). Their activation in the TME is achieved by stimuli, such as environmental stresses or secretory proteins, e.g., growth factors and cytokines, which induce mitogenactivated (ERK) and Jun kinase (JNK) signaling. Upon activation, PSCs are transformed into different CAF subtypes that are major regulators of tumor-stromal crosstalk $[95,96]$. Once activated, PSCs further secrete factors, which promote activation of quiescent PSCs in a feed-forward loop, and this is facilitated in part through paracrine transfer of sEVs containing CD9, CCN2 and miR-21 cargo, driving fibrosis [76,97,98]. In addition, PDAC cells induce proliferation and migration of PSCs by transfer of sEVs containing miR-1246 and miR-1290 to upregulate $\alpha$-smooth muscle actin ( $\alpha$-SMA/ACTA2) as well as procollagen type I C-peptide (PIP) via ERK and Akt signaling [99]. On the other hand, PSC-derived sEVs were reported to influence PDAC cells by stimulating chemokine expression (C-C chemokine ligand 20, CCL20; C-X-C chemokine ligand 1 and 2, CXCL1/2), fostering tumor cell proliferation and migration $[98,100]$. PDAC proliferation was also promoted through the sEV-based transfer of miR-5703, which targets CKLF-like MARVEL transmembrane domain containing 4 (CMTM4), resulting in the activation of the PI3K/Akt pathway by p21-activated kinase (PAK4) [101]. Thus, PSCs and PDAC cells are engaged in an extensive crosstalk utilizing sEVs to enable tumor progression.

\section{3. sEVs in Angiogenesis}

Abundant ECM deposition and extensive fibrosis in the TME can implement a mechanical barrier. This prevents tumor cells from acquiring sufficient oxygen and nutrients, thereby limiting tumor growth. The hypoxic conditions also trigger the release of proangiogenic molecules, such as vascular endothelial growth factor (VEGF) from tumor cells to facilitate angiogenesis. Angiogenesis is a multistep process to generate new blood vessels from preexisting ones [102], thus enabling survival, growth, and metastatic spread of tumors. Pancreatic cancer is characterized by high microvascular density and concomitantly impaired microvessel integrity. These blood vessels are poorly perfused and display a heterogenous distribution in different subtypes $[103,104]$. The combination of both parameters has been associated with early recurrence, metastasis, and short survival after tumor resection [105]. PDAC-derived sEVs contain several cargos that support angiogenesis by activating surrounding stromal cells to induce ECM remodeling as well as neovascularization [106]. In a rat PDAC model, incubation of endothelial cells (ECs) with PDAC-derived sEVs, harboring Tspan8, CD106, or CD49d (Integrin $\alpha 4$ ) triggered the expression of proangiogenic factors, including von Willebrand factor (VWF), TSPAN8, CXCL5, migration inhibitory factor (MIF), C-C chemokine receptor type 1 (CCR1), VEGF, and VEGFR2. This reprogramming induced EC proliferation, migration, sprouting, progenitor maturation and thus neovascularization, independently of VEGF-driven angiogenesis [107]. In addition, PDAC cells were shown to release VEGF-C containing sEVs upon downregulation of the dual-specificity phosphatase-2 (DUSP-2), promoting lymphovascular invasion [108]. Of note, VEGF-C was also associated with vasculogenic mimicry by tumor cells, which is a formation of blood vessel-like structures independent of angiogenesis by endothelial cells. A similar phenotype was reported for Ephrin Type-A Receptor 2 (EphA2) signaling, 
a sEV-resident biomarker in PDAC $[109,110]$. More sEV cargos involved in the regulation of angiogenesis are summarized in Table 1.

\subsection{Immune Cells in the TME}

A major feature of the PDAC TME is the immunosuppressive cellular environment that is able to inhibit innate and adaptive immune responses [111]. Antitumor immunity is triggered by the release of tumor-associated antigens (TAAs) and activation of immune effector cells, such as natural killer (NKs) and CD8+ $\mathrm{T}_{\text {effectors }}$ [112]. The PDAC TME harbors a large amount of immunosuppressive cell types, such as $\mathrm{T}_{\text {regs }}$, M2-TAMs, and immature myeloid-derived suppressor cells (iMDSCs), which inhibit proper CD8+ T-cell responses, functional antigen presentation/lymphocyte activation by dendritic cells (DCs), or the anti-tumor response by M1 macrophages (M1-TAMs) [113]. A vital part of the immunosuppressive signaling in the TME is mediated by sEVs, e.g., by facilitating the transformation of immune cells into immunosuppressive and pro-tumorigenic phenotypes [111]. This helps tumors to bypass immune surveillance by facilitating functional losses in lymphocytes or inhibiting lymphocyte activation and survival [114]. sEVs are involved in the suppression of both innate and adaptive immune responses [115].

\subsubsection{Innate Immunosuppression and Tumor Associated Macrophages}

TAMs are critical components of the TME [116]. Macrophages are involved in numerous biological processes including tissue homeostasis, defense against pathogens and wound healing $[117,118]$. They originate from circulating monocytes and are transformed at sites of inflammation into activated M1 or M2 phenotypes. M1-polarized TAMs are characterized by the expression of pro-inflammatory and anti-tumorigenic cytokines and chemokines, whereas M2-macrophages suppress antitumor immunity, contributing to PDAC progression $[119,120]$. Tumor cells can utilize sEVs to induce the differentiation of M1-TAMs towards a M2-immunosuppressive phenotype [121]. These M2-TAMs not only orchestrate immunosuppression, but also promote radiation- and chemoresistance, angiogenesis, migration, invasion as well as metastasis [122]. M2-polarization was reported upon uptake of PDAC-derived sEVs loaded with intercellular adhesion molecule-1 (ICAM-1) and arachidonic acid (AA), triggering the secretion of pro-angiogenic and prometastatic factors. To this end, ICAM-1 on sEVs interacted with CD11c on macrophages, which facilitated the secretion of pro-tumorigenic molecules and uptake of the respective sEVs was further enhanced by AA [123]. Patient-tumor-sEVs enriched in Ezrin (EZR) also directed M2-polarization in vivo, enhancing liver metastasis [124].

Vice versa, sEVs from M2-macrophages interacted with PDAC tumor cells as well as the extended TME, e.g., M2-derived sEVs with miR-501-3p inhibited transforming growth factor beta receptor 3 (TGFBR3), enabling TGF- $\beta$ signaling, tumor growth, and metastasis of xenografted PDAC in nude mice. Interestingly, miR-501-3p is also highly expressed in PDAC patient tissue [125]. Moreover, sEVs derived from M2-macrophages containing $\mathrm{miR}-155-5 \mathrm{p}$ and $\mathrm{miR}-221-5 \mathrm{p}$ further promoted angiogenesis in vitro by targeting the E2F transcription factor 2 (E2F2). Uptake of the respective sEVs in mice additionally enhanced vascular density and growth of subcutaneous tumors [126]. Transfer of M2-macrophagesEVs with miR-365 reduced sensitivity of PDAC cells to gemcitabine in vitro and in vivo, enhancing migration and invasion of PDAC cells by targeting B-cell translocation gene 2 (BTG2) and activating FAK/AKT signaling [127]. Thus, sEV-based crosstalk between PDAC tumor cells and TAMs has a major function in shaping an immunosuppressive, tumor supporting TME.

\subsubsection{Immunosuppression by Myeloid-Derived Suppressor Cells}

MDSCs are important innate regulators of the immune response. They are a heterogenous group of immature myeloid cells with potent immunosuppressive activity $[128,129]$. In PDAC patients, MDSC frequency in the peripheral blood is associated with metastatic disease and poor clinical outcome [130]. According to their origin from either monocytic or 
granulocytic myeloid cell lineages, MDSCs are classified in two main subgroups: monocytic (M-MDSCs) or granulocytic/polymorphonuclear MDSCs (G/PMN-MDSCs) [129,131]. Upon persistent exposure to inflammatory signals and myeloid growth factors, MDSCs are activated and regulate a variety of immunological and non-immunological pro-tumorigenic functions, including immune evasion, angiogenesis, EMT, and PMN-formation [129,132]. There is even evidence that hypoxic conditions can stimulate the differentiation of MDSCs into M2-TAMs and that MDSCs in general may enhance their pro-tumorigenic activity $[131,133,134]$. Interestingly, MDSCs can be activated by PDAC-sEVs. PDAC cells lacking expression of the tumor suppressor SMAD4 were shown to release sEVs containing miR-1260a and miR-494-3p, which changed the balance between DCs and MDSCs towards a higher number of M- and G-MDSCs, thereby promoting proliferation, glycolysis, and immunosuppression. The expression of SMAD4 is lost in around 55\% of PDACs and associated with a poor prognosis [135]. Thus, loss of the SMAD4 tumor suppressor in PDAC is associated with altering sEV secretion and cargo content to generate an immunosuppressive TME.

\subsubsection{Adaptive Immune Suppression-Targeting T-Cell Activation by DCs and $\mathrm{T}_{\text {regs }}$}

In addition to the innate immune response, PDAC can also bypass the adaptive immunosurveillance utilizing sEVs. In the PDAC TME, DCs are scarce and more frequently detected at the edge of tumors. In patients, more circulating DCs were associated with improved survival [136]. DCs are a diverse population of antigen-presenting cells, which are key modulators of the adaptive immune response that promote antigen-specific immunity and tolerance [137]. DCs facilitate activation of CD8 $+\mathrm{T}_{\text {effector }}$ cells by presenting antigens and releasing immunomodulatory cytokines, such as interleukin-12 (IL-12) and type I interferons to drive antitumor immunity. Additional conditioning of the TME with chemokines, such as CXCL9 and CXCL10 further promotes T-cell attraction and recruitment. DCs also support CD4+ T-cell differentiation towards a $T_{\text {helper }}$ type $1\left(T_{h} 1\right)$-phenotype with antitumor functions [138]. Thus, reprogramming of DCs by tumor-sEVs is a key step in perturbing adaptive, but also innate anti-tumor responses, impairing T-cell efficiency, the expression of Toll-like receptors (TLRs) or interleukins (ILs) [138-140]. For example, uptake of miR-203 in PDAC-derived sEVs by DCs was reported to inhibit the expression of TLR4, tumor necrosis factor- $\alpha$ (TNF- $\alpha$ ), and IL-12 and mediate DC dysfunction [140]. Moreover, transfer of PDAC-sEVs to DCs with mir-212-3p, inhibited the expression of the transcription-factorregulatory-factor-x-associated protein (RFXAP) and mediated downregulation of MHC II receptors as well as failure of CD4+ T-cell activation [141].

In vivo studies further indicated that PDAC-derived sEVs inhibit IL-2-mediated signaling to lymphocytes upon uptake by DCs and macrophages, promoting lymphocyte apoptosis [142]. In line, direct uptake of PDAC-sEVs by leukocytes caused inhibition of proliferation and impaired anti-apoptotic signaling, as well as IL-12-induced $\mathrm{T}_{\mathrm{h}}$-cell proliferation. Moreover, the respective PDAC-sEVs interfered with chemotaxis of leukocytes towards the tumor [142]. The TME of PDACs is also characterized by a high number of inhibitory $\mathrm{T}_{\text {regs. }} \mathrm{T}_{\text {regs }}$ are classified as a subset of CD4+ T-lymphocytes, which express the transcriptional regulator Forkhead-box-protein P3 (FOXP3). They are crucial modulators of the immune system, which help to maintain tolerance against self-antigens, and suppress $\mathrm{T}_{\text {effector }}$ cell activation as well as clonal expansion $[143,144] . \mathrm{T}_{\text {regs }}$ are already detected in, or near early PanINs. Their numbers expand with PDAC progression and elevated levels were associated with bad prognosis for patients [7,145]. A recent study showed that the increased number of $\mathrm{T}_{\text {regs }}$ is partly caused by PDAC-sEVs that foster $\mathrm{T}_{\text {reg }}$ expansion by enhanced expression of FOXP3 [146].

In summary, PDAC-sEVs are vitally implicated in shaping the PDAC TME and evading anti-tumor immune surveillance by the innate and adaptive immune system. However, sEVs can also enter the circulation to mediate effects over longer distances, such as faciliating organotropic metastasis. Circulating sEVs can even be utilized as a platform for biomarkers associated with diagnosis and prognosis of PDAC. 


\section{6. sEVs in PDAC Metastasis}

Ample evidence has demonstrated that PDAC-derived sEVs not only act as extracellular signaling hubs for TME remodeling, but also help to shape and establish PMNs in distinct organs.

\subsection{PDAC-Derived sEVs and Formation of Distant PMNs}

PDACs are characterized by a high propensity to metastasize, as the majority of PDAC patients present with metastases at the time of diagnosis $[2,82]$. The main sites for PDAC metastasis are the liver and lungs, but also the peritoneal cavity [82]. The formation of tumor metastases in distinct organs is dependent on the establishment of suitable PMNs. PMNs facilitate cancer dissemination by supporting survival and spread of cancer initiating cells (CIC) [147]. Recently, sEVs which express specific integrin combinations, such as integrin av $\beta 5$, were reported to drive organ-specific metastasis, i.e., in the liver by facilitating the respective PMN formation with the help of resident cell populations. Integrins are important signaling mediators during metastasis, which mediate cell-ECM adhesion, mechano-signaling, and cell migration by acting as transmembrane receptors for various physiological extracellular ligands. The integrin expression pattern on the cells surface is therefore a key factor in determining the behavior of cells in response to microenvironmental cues. Once dysregulated, altered integrin expression has been linked to various steps during cancer progression, including priming of metastatic niches, extravasation, homing of CICs to distant sites, as well as metastatic colonization $[148,149]$. Interestingly, integrins are also vital sEV cargos and can be recycled from the cell surface via endocytosis into MVBs and eventually sEVs $[150,151]$. In many instances recycling and packaging of integrins into MVBs is dependent on their interaction with Tspans that are a major sEV cargo class $[24,47,152]$. During PDAC progression, sEVs with specific integrin expression patterns were shown to mediate PMN formation in liver and lungs [153,154]. Costa-Silva et al. reported, that PDAC-sEVs crucially contribute to liver metastasis by transferring migration inhibitory factor (MIF) to Kupffer cells (KCs) in the liver. This resulted in increased TGF- $\beta$ expression by KCs, which in turn activated hepatic stellate cells (HSCs) to secret fibronectin and induce the expression of proinflammatory mediators to facilitate formation of a suitable liver niche. This was corroborated in PDAC patients with liver metastases, which presented with elevated levels of MIF-positive plasma sEVs as compared to healthy control subjects, or patients with 5-year progression-free PDAC [153]. As described above, PDAC-sEVs positive for integrin $\alpha v \beta 5$ were shown to facilitate the establishment of pre-metastatic liver niches, whereas integrins $\alpha 6 \beta 4$ - or $\alpha 6 \beta 1$ directed niche formation and metastases in the lung [154]. In line, our group has recently demonstrated that Protein kinase D1 (PRKD1) expression was significantly downregulated in many PDACs, compared with non-tumor tissue. Loss or inhibition of PRKD1 strongly enhanced sEV release from different PDAC cells and changed the expression of integrins in cells as well as secreted sEVs to high levels of integrins $\alpha 6 \beta 4$, while impairing expression of integrin $\beta 5$. Thus, injection of PRKD1 ${ }^{\mathrm{KO}}$-sEVs effectively enhanced lung metastasis of Panc1 cells in xenografted mice. We have also demonstrated that the enhanced expression of integrins $\alpha 6 \beta 4$ in PRKD1 ${ }^{\mathrm{KO}}$-sEVs was facilitated by transcriptional upregulation in cells, as well as increased endosomal recycling and packaging of integrin $\alpha 6 \beta 4$ from the cell surface into sEVs in a Tspan CD82-dependent manner. Moreover, autochthonous Prkd1 knockout mice in a Kras ${ }^{\mathrm{G} 12 \mathrm{D}}$ background showed predominant lung and no visible liver metastasis. This may be attributed to the abrogated formation of integrin $\alpha \mathrm{v} \beta 5$ dimers due to low levels of integrin $\beta 5$ in PRKD $1^{\mathrm{KO}}$-cells and -sEVs. The PMN in the lung was ultimately established upon uptake and reprogramming of PRKD ${ }^{\mathrm{KO}}-$ sEVs by lung fibroblasts, which induced expression of proinflammatory regulators S100A6, A13, and A16. To this end, transfer of respective s100a mRNAs by sEVs was also suggested [47]. In summary, these data indicate that PDAC do not only utilize their sEVs to communicate in the local TME, but also over long distances via the blood flow to establish PMNs and facilitate subsequent PDAC dissemination. 


\section{2. sEVs in PDAC Tumor Proliferation, EMT, Invasion, and Metastasis}

Once PMNs at distant organs have been established, PDAC cells need to acquire a motile, invasive phenotype, e.g., undergoing EMT to subsequently enter the circulation and metastasize. During EMT, tumor cells loose epithelial features, such as E-cadherin expression and acquire a mesenchymal phenotype by expressing vimentin, fibronectin and N-cadherin as well as MMPs $[155,156]$. EMT is controlled by zinc-finger transcription factors, such as SNAIL, SLUG, and TWIST downstream of growth factor signaling, e.g., EGF, TGF $\beta$, or Wnt / $\beta$-catenin pathways [157-160]. PDAC-sEVs affect these processes in an auto- and paracrine manner. PDAC-derived sEVs containing Tenascin-c (TNC) were described to drive PDAC migration, invasion, and EMT by mediating Wnt/ $\beta$-catenin signaling. TNC-containing PDAC-sEVs also increased PDAC proliferation by activating NF- $k B$ [161]. PDAC metastasis is further regulated by signaling through miRNAs. The RNA-binding protein LIN28B was shown to promote PDAC growth and metastasis by inhibiting the biogenesis of let-7 family miRs [162]. In PDAC tumor-bearing xenografted mice, injection of LIN28B-positive sEVs activated LIN28B/let-7/high-mobility group AThook 2 (HMGA2)/ platelet derived growth factor subunit B (PDGFB) signaling to facilitate PDAC liver metastasis [162].

Moreover, blood vessels are attracted to tumors, by inducing neoangiogenesis to secure oxygen/nutrient supply and foster metastatic dissemination. As detailed in Section 5.3, angiogenesis of blood and lymphatic vessels is facilitated by sEVs, yet this process is not only limited to the TME but also supports tumor growth at metastatic sites [163]. Once metastases are established at distant organs, prognosis for patients is exceedingly bad. This is even further aggravated when PDAC tumors have acquired additional resistance against radio- and chemotherapies $[5,164]$.

\section{7. sEVs in Chemoresistance}

Resistance towards chemotherapy is a major limiting factor for curative treatment of PDAC patients. Chemoresistance is multifactorial, and depends on parameters, such as tumor burden, tumor heterogeneity, physical barriers due to fibrosis, the immune system as well as undruggable cancer drivers [165]. Gemcitabine (GEM) chemotherapy is one of the agents used as standard of care for PDAC treatment and resistance towards GEM is a severe problem, reducing the efficacy of the response in advanced or metastatic disease [166]. Tumor cells have adopted different resistance mechanisms to evade chemotherapy, including sEVs. For example, paracrine transfer of miRNAs to surrounding PDAC cells by PDAC-derived sEVs facilitates chemoresistance. GEM-resistant PDAC cells were shown to transduce drug resistance to non-resistant cells by sEV-based transfer of miR-210, which activated the mTOR pathway in vitro and in vivo, and treatment of non-resistant cells with the respective sEVs also stimulated their proliferative and anti-apoptotic capacities [167]. Moreover, miR-155-loaded PDAC-sEVs from drug resistant cells transduced drug resistance by downregulation of deoxycytidine kinase (DCK), a GEM-metabolizing enzyme. PDAC patients with high levels of miR-155 in PDAC tissue were further reported to have a poor prognosis [168]. In addition, transfer of transcripts for ROS-detoxifying superoxide dismutase 2 (SOD2) and catalase (CAT) by GEM-resistant-PDAC-sEVs caused increased expression of the respective mRNAs, impairing GEM-mediated ROS production [169]. Thus, sEVs are potent regulators of chemoresistance in PDAC.

Table 1 represents a summary of sEV cargos and their respective functions in PDAC. 
Table 1. sEV cargos and their respective functions in PDAC.

\begin{tabular}{|c|c|c|c|c|c|}
\hline Biological Process & Donor Cell & Recipient Cell & sEV Cargo & Function in PDAC & Reference \\
\hline \multirow[t]{7}{*}{$\begin{array}{l}\text { Precancerous } \\
\text { diseases (PD) }\end{array}$} & PSCs & PSCs & $\operatorname{miR}-21-5 p$ & $\begin{array}{l}\text { miR-21-5p regulates CCN2 } \\
\text { expression, facilitating proliferation } \\
\text { and collagen deposition }\end{array}$ & [76] \\
\hline & MSCs & PACs & Klotho & $\begin{array}{l}\text { Attenuates caerulein- induced } \\
\text { activation of NF- } \mathrm{B} \text {, stimulating } \\
\text { growth and apoptosis resistance }\end{array}$ & [170] \\
\hline & hPDAC cells & DCs & miR-212-3p & $\begin{array}{c}\text { Inhibition of RFXAP, causing MHC II } \\
\text { downregulation and CD4+ T-cell } \\
\text { activation (also relevant in IS and } \\
\text { MET) }\end{array}$ & [141] \\
\hline & hPDAC cells & DCs & miR-203 & $\begin{array}{l}\text { Inhibition of DC function by } \\
\text { suppressing TLR4, TNF- } \alpha \text {, and IL-12 } \\
\text { expression (also relevant in IS) }\end{array}$ & [140] \\
\hline & hPDAC cells & MDSCs & miR-1260a & $\begin{array}{l}\text { Reprogramming of } \mathrm{g} / \mathrm{mMDSCs} \\
\text { bolstering proliferation and } \\
\text { glycolysis, thus establishing a } \\
\text { immunosuppressive TME (also } \\
\text { relevant in IS) }\end{array}$ & [135] \\
\hline & rPDAC cells & rPDAC cells & CD151 & Induction of EMT and migration & [171] \\
\hline & rPDACCIC & rPDAC cells & Cld7 & $\begin{array}{l}\text { Reprogramming of non-metastatic } \\
\text { cells to increase their invasiveness } \\
\text { (also relevant in AG and MET) }\end{array}$ & [172] \\
\hline \multirow[t]{8}{*}{$\begin{array}{l}\text { Immunosuppression } \\
\text { (IS) }\end{array}$} & hPDAC cells & Macrophages & ICAM-1/AA & $\begin{array}{l}\text { ICAM-1 interacts with } \\
\text { surface-exposed CD11c on } \\
\text { macrophages promoting M2 } \\
\text { polarization, triggering angiogenesis } \\
\text { and metastasis. AA facilitates } \\
\text { sEV-uptake by macrophages. }\end{array}$ & [123] \\
\hline & hPDAC cells & Macrophages & miR-301a-3p & (also relevant in MET) & {$[90]$} \\
\hline & hPDAC cells & Macrophages & EZR & $\begin{array}{l}\text { M2 polarization of macrophages, } \\
\text { promoting liver metastasis }\end{array}$ & [124] \\
\hline & hPDAC cells & DCs & $\operatorname{miR}-212-3 p$ & (also relevant in PD and MET) & [141] \\
\hline & hPDAC cells & DCs & miR-203 & (also relevant in PD) & [140] \\
\hline & hPDAC cells & DCs & miR-1260a & (also relevant in PD) & [135] \\
\hline & $\begin{array}{l}\text { Patient plasma } \\
\text { sEVs }\end{array}$ & BCs & TAA & $\begin{array}{l}\text { Trapping of anti-TAA-antibodies and } \\
\text { complement-mediated cytotoxicity, } \\
\text { preventing B-lymphocytes from } \\
\text { properly engaging tumors }\end{array}$ & [173] \\
\hline & hPDAC cells & T lymphocytes & FOXP3 & $\begin{array}{l}\text { Enhanced sEV-induced FOXP3 } \\
\text { expression and Treg expansion } \\
\text { mediated by the ATM-AMPK- } \\
\text { SIRT1/2/6-FOXO1A/FOXO3A axis, } \\
\text { resulting in impaired anti-tumor } \\
\text { immunity of T lymphocytes against } \\
\text { PDAC cells }\end{array}$ & [146] \\
\hline Angiogenesis (AG) & rPDAC cells & $\mathrm{EC}$ & Tspan8/106/49d & $\begin{array}{l}\text { VEGF-independent regulation of } \\
\text { angiogenesis-related genes, } \\
\text { triggering EC proliferation, } \\
\text { maturation of EC progenitors, } \\
\text { migration and sprouting }\end{array}$ & [107] \\
\hline
\end{tabular}


Table 1. Cont

\begin{tabular}{|c|c|c|c|c|c|}
\hline Biological Process & Donor Cell & Recipient Cell & sEV Cargo & Function in PDAC & Reference \\
\hline & hPDAC cells & HMVEC & miR-27a & $\begin{array}{l}\text { Suppression of BTG2, inducing } \\
\text { proliferation, migration and } \\
\text { angiogenesis }\end{array}$ & [174] \\
\hline & hPDAC cells & $\mathrm{EC}$ & Circ-IARS & $\begin{array}{l}\text { Increase of endothelial cell } \\
\text { permeability and angiogenesis, } \\
\text { promoting invasiveness. } \\
\text { Downregulation of miR-122 and ZO-1 } \\
\text { as well as upregulation of active } \\
\text { RhoA-GTP and F-Actin, contributing } \\
\text { to PDAC invasion (also relevant in } \\
\text { MET) }\end{array}$ & [175] \\
\hline & $\begin{array}{c}\text { M2 } \\
\text { macrophages }\end{array}$ & EC & $\begin{array}{l}\operatorname{miR}-155-5 p \\
\operatorname{miR}-221-5 p\end{array}$ & $\begin{array}{l}\text { Targeting of E2F2 enhances vascular } \\
\text { density and tumor growth }\end{array}$ & [126] \\
\hline & hPDAC cells & EC & VEGF-C & $\begin{array}{l}\text { Downregulation of DUSP-2 facilitates } \\
\text { release of VEGF-C-containing sEVs, } \\
\text { resulting in lymphovascular invasion }\end{array}$ & [108] \\
\hline & $\mathrm{rPaCIC}$ & rPDAC cells & Cld7 & (also relevant in PD and MET) & [172] \\
\hline \multirow[t]{6}{*}{ Proliferation } & hPDAC & PSCs & $\begin{array}{l}\operatorname{miR}-1246 \\
\operatorname{miR}-1290\end{array}$ & $\begin{array}{c}\text { Upregulation of } \alpha \text {-SMA, production } \\
\text { of PIP and activation of ERK, Akt } \\
\text { signaling, inducing proliferation and } \\
\text { migration }\end{array}$ & [99] \\
\hline & hPDAC cells & PHFF & mRNA-hTERT & $\begin{array}{l}\text { Transformation of non-malignant } \\
\text { pancreatic fibroblasts, delaying aging } \\
\text { and stimulating proliferation }\end{array}$ & [176] \\
\hline & hPDACSCs & hPDAC cells & $\operatorname{miR}-210$ & $\begin{array}{l}\text { Activation of mTOR pathway, } \\
\text { stimulating proliferation and } \\
\text { apoptosis resistance }\end{array}$ & [167] \\
\hline & PSCs & PSCs & miR-21-5p & (also relevant in PD) & [76] \\
\hline & PSCs & hPDAC cells & miR-5703 & $\begin{array}{l}\text { Targeting of CMTM4, promoting } \\
\text { proliferation due the activation of } \\
\text { PI3K/Akt pathway by PAK4 }\end{array}$ & [101] \\
\hline & CAFs & hPDAC cells & $\begin{array}{l}\text { de novo } \\
\text { metabolites }\end{array}$ & $\begin{array}{c}\text { Reprogramming the energy } \\
\text { metabolism of PDAC cells, enhancing } \\
\text { the Warburg effect, promoting } \\
\text { growth and survival }\end{array}$ & [91] \\
\hline \multirow[t]{3}{*}{ Metastasis (MET) } & hPDAC cells & hPDAC cells & CD44v6 & $\begin{array}{c}\text { Activation of Wnt / } \beta \text {-catenin } \\
\text { signaling, increasing expression of } \\
\text { PAI-1, MMPs and TIMP-1, enhancing } \\
\text { cell migration and metastasis. } \\
\text { Promotes motility and invasion by } \\
\text { interacting with integrins and } \\
\text { proteases }\end{array}$ & [177] \\
\hline & rPDAC cells & rPDAC cells & CD151/Tspan8 & $\begin{array}{l}\text { Increase in expression of } \\
\text { proinflammatory regulators and } \\
\text { EMT-associated transcripts as well as } \\
\text { promotion of ECM remodeling, } \\
\text { fostering angiogenesis and metastasis }\end{array}$ & [171] \\
\hline & $\mathrm{rPaCIC}$ & rPDAC cells & Cld7 & (also relevant in PD and AG) & [172] \\
\hline
\end{tabular}


Table 1. Cont.

\begin{tabular}{|c|c|c|c|c|c|}
\hline Biological Process & Donor Cell & Recipient Cell & sEV Cargo & Function in PDAC & Reference \\
\hline & hPDAC cells & $\begin{array}{l}\text { hPDAC } \\
\text { cells/PSCs }\end{array}$ & Lin28B & $\begin{array}{c}\text { Inhibition of let-7 family } \\
\text { miR-biogenesis, promoting growth } \\
\text { and liver metastasis. } \\
\text { Promotion of PSC recruitment by } \\
\text { upregulating PDGFB resulting in the } \\
\text { activation of the } \\
\text { Lin28B/let7/HMGA2/PDGFB } \\
\text { signaling pathway }\end{array}$ & [178] \\
\hline & $\begin{array}{l}\mathrm{m} / \mathrm{hPDAC} \\
\text { cells }\end{array}$ & $\begin{array}{l}\text { KCs } \\
\text { HSCs }\end{array}$ & MIF & $\begin{array}{l}\text { Stimulation of TGF- } \beta \text { by KCs, } \\
\text { triggering fibronectin production of } \\
\text { HSCs, fostering pre-metastatic niche } \\
\text { formation in the liver }\end{array}$ & [153] \\
\hline & hPDAC cells & hPDAC cells & Plectin & $\begin{array}{l}\text { Promotion of proliferation, migration, } \\
\text { and invasion }\end{array}$ & [179] \\
\hline & hPDAC cells & hPDAC cells & ZIP4 & $\begin{array}{l}\text { Promotion of proliferation, migration, } \\
\text { and invasion }\end{array}$ & [180] \\
\hline & $\mathrm{CM} /$ serum & hPDAC cells & $\operatorname{miR}-222$ & $\begin{array}{c}\text { Impaired expression, } \\
\text { phosphorylation and nuclear exit of } \\
\text { p27 via PPP2R2A/Akt, promoting } \\
\text { proliferation and invasiveness }\end{array}$ & [181] \\
\hline & hPDAC cells & Macrophages & miR-301a-3p & $\begin{array}{l}\text { M2 polarization of macrophages and } \\
\text { HIF1 } \alpha / 2 \alpha \text {-promoted activation of } \\
\text { PI3K-signaling, fostering survival, } \\
\text { proliferation, and metastasis (also } \\
\text { relevant in IS) }\end{array}$ & [90] \\
\hline & mPDAC cells & mPDAC cells & miR-339-5p & $\begin{array}{l}\text { Downregulation of ZNF689, } \\
\text { inhibiting migration and invasion }\end{array}$ & [182] \\
\hline & Macrophages & hPDAC cells & miR-501-3p & $\begin{array}{l}\text { Inhibition of TGFBR3 and activation } \\
\text { of TGF- } \beta \text { signaling, inducing growth, } \\
\text { and metastasis }\end{array}$ & [125] \\
\hline & hPDAC cells & EC/HUVEC & Circ-IARS & (also relevant in AG) & [175] \\
\hline & hPDAC serum & hPDAC cells & Circ-PDE8A & $\begin{array}{l}\text { Counteracting of miR-338 activates } \\
\text { MACC/MET/ERK/Akt signaling, } \\
\text { inducing invasive growth }\end{array}$ & [183] \\
\hline & hPDAC cells & $\begin{array}{l}\text { Lung } \\
\text { fibroblasts }\end{array}$ & $\begin{array}{l}\text { Integrin } \alpha 6 \beta 4 \\
\text { Integrin } \alpha 6 \beta 1\end{array}$ & $\begin{array}{l}\text { Lungtropic metastasis } \\
\text { Packaging of } \alpha 6 \beta 4 \text { into sEVs in a } \\
\text { CD82-dependent manner in cells } \\
\text { with loss of PRKD1 }\end{array}$ & {$[47,154]$} \\
\hline & hPDAC cells & Macrophages & EZR & $\begin{array}{c}\text { M2 polarization of macrophages, } \\
\text { triggering metastasis }\end{array}$ & [124] \\
\hline & hPDAC cells & KC & Integrin $\alpha v \beta 5$ & Livertropic metastasis & [153] \\
\hline & hPDAC cells & hPDAC cells & miR-23b-3p & $\begin{array}{l}\text { Promotion of proliferation, migration } \\
\text { and invasion }\end{array}$ & [184] \\
\hline & hPDAC cells & DCs & miR-212-3p & (also relevant in PD and IS) & [141] \\
\hline & hPDAC cells & hPDAC cells & VEGF-C & (also relevant in AG) & [108] \\
\hline & hPDAC cells & hPDAC cells & miR-125b-5p & $\begin{array}{c}\text { Inhibition of STARD13, enhancing } \\
\text { EMT as well as migration and } \\
\text { invasion }\end{array}$ & [185] \\
\hline
\end{tabular}


Table 1. Cont

\begin{tabular}{|c|c|c|c|c|c|}
\hline Biological Process & Donor Cell & Recipient Cell & sEV Cargo & Function in PDAC & Reference \\
\hline & hPDAC cells & hPDAC cells & lnc-Sox2ot & $\begin{array}{l}\text { Competitive binding to miR-200 } \\
\text { family upregulates Sox } 2 \text { expression, } \\
\text { inducing EMT and stem cell-like } \\
\text { properties of PDAC cells, thus } \\
\text { contributing to invasion and } \\
\text { metastasis }\end{array}$ & [186] \\
\hline & CAFs & hPDAC cells & $\begin{array}{c}\text { ANXA6/ } \\
\text { LRP1/TSP1 }\end{array}$ & $\begin{array}{c}\text { Increased PDAC aggressiveness and } \\
\text { metastasis }\end{array}$ & [187] \\
\hline \multirow[t]{5}{*}{$\begin{array}{l}\text { Chemoresistance } \\
\text { (CR) }\end{array}$} & CAFs & hPDAC cells & $\begin{array}{l}\text { Snail } \\
\text { miR-146a }\end{array}$ & $\begin{array}{l}\text { Promotion of survival, proliferation } \\
\text { and drug resistance }\end{array}$ & [188] \\
\hline & CAFs & hPDAC cells & $\operatorname{miR}-106 b$ & $\begin{array}{l}\text { Downregulation of TP53INP1, } \\
\text { promoting proliferation and drug } \\
\text { resistance }\end{array}$ & [189] \\
\hline & hPDAC cells & hPDAC cells & miR-155 & $\begin{array}{c}\text { Downregulation of DCK or } \\
\text { upregulation of ROS-detoxifying } \\
\text { genes SOD2 and CAT, promoting } \\
\text { drug resistance }\end{array}$ & [169] \\
\hline & $\begin{array}{l}\mathrm{M} 2 \\
\text { macrophages }\end{array}$ & hPDAC cells & miR-365 & $\begin{array}{l}\text { Upregulation of } \\
\text { triphospho-nucleotide pool in PDAC } \\
\text { cells, induction of cytidine deaminase } \\
\text { activation or targeting of BTG2 to } \\
\text { stimulate FAK/AKT pathway, } \\
\text { triggering drug resistance }\end{array}$ & [127] \\
\hline & hPDAC cells & hPDAC cells & EphA2 & Promotion of drug resistance & [190] \\
\hline
\end{tabular}

\section{8. sEVs as Biomarkers for Prognosis and Prediction}

Besides a prominent role of circulating PDAC-sEVs in facilitating the formation of PMNs and systemic chemoresistance, the respective sEVs have also been proposed as effective biomarker platforms, accessible by blood liquid biopsy. It is thus tempting to utilize sEVs and their cargos for early detection of PDAC and their differentiation from more benign pancreatic diseases, such as pancreatitis. In this context, sEV-resident glypican-1 (GPC-1) is one of the most studied PDAC markers to date. It was originally discovered by Melo et al. using animal and human cell lines and presented with a sensitivity/specificity of $100 \%$, upon detection by transmission electron microscopy on sEVs. ELISA detection reduced the sensitivity and specificity to $82.14 \%$ and $75 \%$, respectively [191]. Further validation of these findings using alternative sEV purification techniques after sampling sEVs from peripheral or portal vein blood has demonstrated a sensitivity of $64 \%$, whereas the specificity was $90 \%$. This was still more sensitive than fine needle biopsy and the current gold-standard maker carbohydrate antigen 19-9 (CA19-9). In their hands, the best diagnostic accuracy was obtained when all three methods were combined or by using GPC-1-sEVs together with serum CA19-9 [192]. However, it has to be noted that a validation attempt for GPC-1, as part of another study using ELISAs to detect sEVs, identified no significant difference for PDAC patient samples in respect to benign pancreatic conditions. Thus, further validation and standardization of sEV purification as well as detection methods are required to achieve reproducible results for broad clinical diagnostic use [193]. A challenge to identify viable biomarkers is the reliable differentiation of early-stage cancer from benign pancreatic processes. To this end, EphA2 has been tested as possible biomarker in sEVs, which achieved a sensitivity and specificity of $91 \%$ and $85 \%$, respectively, for identifying stage I and II PDAC compared with healthy controls. Moreover, it was also possible to utilize EphA2 to differentiate stage I and II PDAC from pancreatitis with a sensitivity/specificity of $86 \% / 85 \%$, respectively [110]. Others used 
multiple biomarkers to increase specificity for the detection of PDAC. To this end, a PDACsEV marker panel with EGFR, EpCAM, HER2, mucin-1 (MUC1), GPC-1, and Wnt family member 2 (WNT2) was described that reached a sensitivity of $95 \%$, specificity of $81 \%$, and accuracy of $88 \%$ in a prospective cohort of 43 subjects [194]. In addition to proteins also sEV-resident miRNAs were investigated as a potential diagnostic tool for the early detection of PDAC. Serum-derived sEVs from PDAC patients were reported to contain elevated levels of miR-192-5p, miR-19a-3p, and miR-19b-3p, when compared to healthy controls $[195,196]$. Additional studies described significantly more miR-10b, miR-17-5p and miR-21 in PDAC patient samples [197-200]. Interestingly, miR-21 was also increased in different solid tumors, suggesting a common mechanism involved in carcinogenesis, yet this also limits its use as a PDAC-specific biomarker [201].

sEVs are not only proposed for diagnostic use, but also to identify markers with prognostic value. It has been shown that increased levels of ANXA6-positive sEVs correlate with poor prognosis [187]. Furthermore, programmed death-ligand 1 (PD-L1) on sEVs was used as a prognostic marker, associating high levels with significant shorter average postresection survival times [202]. The sEV cargo EpCAM was also investigated as a prognostic marker. Analysis of sEVs from patients with metastatic or non-resectable locally advanced PDAC indicated higher levels of EpCAM correlated with shorter progression-free and overall survival [203].

A major prognostic factor for PDAC is metastasis. PDAC-derived sEVs were described to induce profibrogenic activities to facilitate the formation of PMNs. This has been demonstrated by Costa-Silva et al., whereby sEVs with MIF helped to establish PMNs in the liver, as described in Section 6.1 [153]. Moreover, the amount of GPC-1 in sEVs was positively correlated with distant metastasis [191]. Thus, sEV-based biomarker analysis has the potential to develop into a potent tool for clinical use. Advantages of sEVs include protection of protein cargos from proteolytic cleavage as well as preventing the degradation of nucleic acids [30]. Moreover strategies have been developed to enrich tumor-specific sEVs by immune purification to increase specificity and sensitivity of sEV analyses [204]. Castillo et al. have identified a set of sEV surface markers: Claudin 4 (CLDN4), EPCAM, CD151, Galectin 3 Binding Protein (LGALS3BP), and Histone H2B type 2-E and F (HIST2H2BE, HIST2H2BF) to enrich PDAC-specific sEVs after liquid biopsy, thus enabling a more sensitive detection of mutated KRAS [205]. We therefore suggest that similar strategies may be employed to improve the analysis of other diagnostic or prognostic cargos. A comprehensive summary of diagnostic and prognostic sEV biomarkers for PDAC is presented in Table 2.

Table 2. sEV biomarkers for diagnosis and prognosis of PDAC.

\begin{tabular}{cccc}
\hline Source & sEV Cargo & Diagnostic/Prognostic Function & Reference \\
\hline Plasma & miR-16 & (Early) diagnosis & {$[206]$} \\
Serum & miR-196a & & \\
& CA19-9 & & \\
& miR-20a & & \\
miR-21 & & \\
miR-24 & Diagnosis and prognosis \\
Serum & miR-25 & & {$[208]$} \\
& miR-99a & & {$[198]$} \\
\hline Serum & miR-191 & (Early) diagnosis & {$[198]$} \\
Serum & miR-1290 & Diagnosis & {$[199]$} \\
Serum & miR-21 & Diagnosis & {$[200]$} \\
\hline Portal vein blood & & Diagnosis
\end{tabular}


Table 2. Cont.

\begin{tabular}{|c|c|c|c|}
\hline Source & sEV Cargo & Diagnostic/Prognostic Function & Reference \\
\hline Plasma & $\operatorname{miR}-10 b$ & Diagnosis & [209] \\
\hline Plasma & $\begin{array}{c}\text { High miR-10b } \\
\text { miR-21 } \\
\text { miR-30c } \\
\text { miR-181a } \\
\text { Low miR-let7a }\end{array}$ & Diagnosis & [197] \\
\hline Plasma & miR-196a & Diagnosis & [210] \\
\hline Plasma & $\begin{array}{l}\text { miR-122-5p } \\
\text { miR-125b-5p } \\
\text { miR-192-5p } \\
\text { miR-193b-3p } \\
\text { miR-221-3p } \\
\text { miR-27b-3p }\end{array}$ & Diagnosis and prognosis & [211] \\
\hline Portal vein blood & miR-451a & Recurrence and prognosis & [199] \\
\hline Pancreatic juice & miR-155 & Diagnosis & [200] \\
\hline Serum & $\operatorname{mir}-1226$ & Diagnosis and prognosis & [212] \\
\hline Serum & $\begin{array}{c}\text { miR-1246 } \\
\text { miR-4644 } \\
\text { miR-3976 } \\
\text { miR-4306 } \\
\text { CD44v6 } \\
\text { Tspan8 } \\
\text { EpCAM } \\
\text { MET } \\
\text { CD104 }\end{array}$ & Diagnosis & [213] \\
\hline Plasma & MIF & Prognosis & [153] \\
\hline Serum & GPC1 & Diagnosis and prognosis & [191] \\
\hline Plasma & $\begin{array}{c}\text { EGFR } \\
\text { EpCAM } \\
\text { MUC1 } \\
\text { GPC1 } \\
\text { WNT2 }\end{array}$ & Diagnosis & [194] \\
\hline Plasma & EphA2 & Diagnosis & [110] \\
\hline Plasma & $\begin{array}{l}\text { EGFR } \\
\text { CA19-9 }\end{array}$ & $\begin{array}{c}\text { Proposed to have diagnostic } \\
\text { potential }\end{array}$ & [214] \\
\hline Serum & CKAP4 & Diagnosis and monitoring & [215] \\
\hline Serum & c-MET & Prognosis & [202] \\
\hline Serum & PD-L1 & Prognosis & [202] \\
\hline Plasma & $\begin{array}{c}\text { CLDN4 } \\
\text { EpCAM } \\
\text { CD151 } \\
\text { LGALS3BP } \\
\text { HIST2H2BE } \\
\text { HIST2H2BF }\end{array}$ & $\begin{array}{c}\text { Surface marker for } \\
\text { enrichment of PDAC-sEVs }\end{array}$ & [205] \\
\hline Plasma & EpCAM & Prognosis & [203] \\
\hline Circulating sEVs & CD44v6 & Prognosis & [216] \\
\hline Circulating sEVs & C1QBP & Prognosis & [216] \\
\hline Serum & ANXA6 & Potential biomarker & [187] \\
\hline Plasma & lnc-Sox2ot & Prognosis & [186] \\
\hline
\end{tabular}




\section{Therapeutic sEVs}

The use of sEVs as therapeutic vehicles is still in its early development. A promising study by Kamerkar et al. in 2017 modified sEVs from fibroblast-like mesenchymal cells with siRNAs or shRNAs against mutated and wildtype KRASG12D (iExosomes). Subsequent sEV-treatment of mice with PDAC tumors in a Kras ${ }^{\mathrm{G} 12 \mathrm{D}}$ background for 30 days demonstrated a significant reduction in tumor size in respect to the untreated control mice. A comparison to liposomes loaded with the same cargo further indicated superior size reduction in the iExosome treatment group. Interestingly, these effects were even evident after 200 days of treatment and survival of mice was significantly increased. This concept is currently also evaluated in a Phase I clinical trial in PDAC patients with a KRAS ${ }^{G 12 D}$ mutation (NCT03608631) [217]. In another study, paclitaxel-containing sEVs from MSCs were shown to reduce PDAC cell proliferation [218]. Recently, sEVs derived from bone marrow mesenchymal stem cells (BM-MSCs) were loaded with a combination of siRNA against galectin-9 and engineered to carry oxaliplatin (OXA) prodrug on their surface (iEXO-OXA). Galectin-9 was used to block Galectin9/dectin-1 signaling to overt immunosuppression by M2 macrophages, whereas the chemotherapeutic agent OXA-prodrug was introduced to trigger immunogenic PDAC cell death (ICD). In vivo-treatment of established Panc-02 tumors using these iEXO-OXA nanoparticles thus effectively stimulated innate and adaptive anti-tumor immune responses, enhanced ICD and infiltration by cytotoxic T-lymphocytes as well as promoted DC maturation [219].

However, there are still many improvements required concerning targeting of engineered sEVs to specific cell populations by utilizing either natural tropism of sEVs or in promoting the development of SEV modification strategies, yet initial research is promising and may help to offer novel treatment avenues for PDAC.

\section{Conclusions and Perspectives}

In this review, we have discussed the roles of sEVs (exosomes) in PDAC initiation, tumor growth, progression, angiogenesis, immune evasion, and metastasis. Extensive research in the last years has indicated that PDACs are characterized by an extensive crosstalk via secretion of sEVs with the cellular components of their TME. There is ample evidence that sEV-based interactions between PDAC cells and CAFs or PSCs, TAMs, T-cells as well as other immune cells (Section 5) regulate tumor growth, chemoresistance, immune evasion, and invasiveness (Sections 5-7, Figure 1). Interestingly, these interactions are not only limited to short-range communication in the TME, but also complemented by a vital role of sEVs in the establishment of distant PMNs by the distribution of sEVs through the blood circulation (Section 6.1). Thus, sEVs function as vital signaling hubs during PDAC progression and metastasis. Different $\mathrm{sEV}$ cargo classes facilitate the reprogramming of target cells, which include lipids, proteins, miRNAs, mRNAs, but also long non-coding or circular RNAs. The respective cargos and their roles in PDAC evolution are summarized in Table 1. Additionally, there is increasing evidence that circulating sEVs may be utilized as effective biomarker platforms for diagnosis or prognosis. To this end, different combinations of markers and cargo classes have been evaluated to classify disease states or treatment responses (Table 2). However, there is still extensive research needed to establish minimal classifiers that are sensitive and specific enough for adoption in routine clinical use. One major problem of liquid biopsies is the diverse origin of $\mathrm{sEVs}$ present in the circulation. Although tumor cells are known to secrete a large amount of sEVs [86], other cells significantly contribute sEVs and cargos to the sampled biopsies. Thus, it would be advantageous to purify or enrich tumor-specific sEVs from the circulation. First steps have been taken in this direction utilizing immuno-enrichment of sEVs [204,205] (Section 8), however sensitivity and specificity still need to be optimized for routine clinical use. There are also studies that have used sEVs as therapeutic vehicles [217,218] (Section 9). This is an exciting and promising use-case. To exploit a therapeutic function for sEVs, the nanovesicles need to be extensively modified during biogenesis or post-release. Moreover, specific targeting will be required $[220,221]$ and the cargo composition of sEVs will need to be 
specifically adapted. There are already studies on the way to optimize the methodology for these modifications, which even include the generation of artificial engineered sEVs [222]. Yet considering the challenges, extensive research will be needed before such applications will be ready for routine clinical use. Nevertheless, sEV research over the last years has greatly contributed to a better understanding of the complex mechanisms that drive PDAC initiation, progression, and metastatic dissemination and will hopefully soon translate into practical therapeutic options.

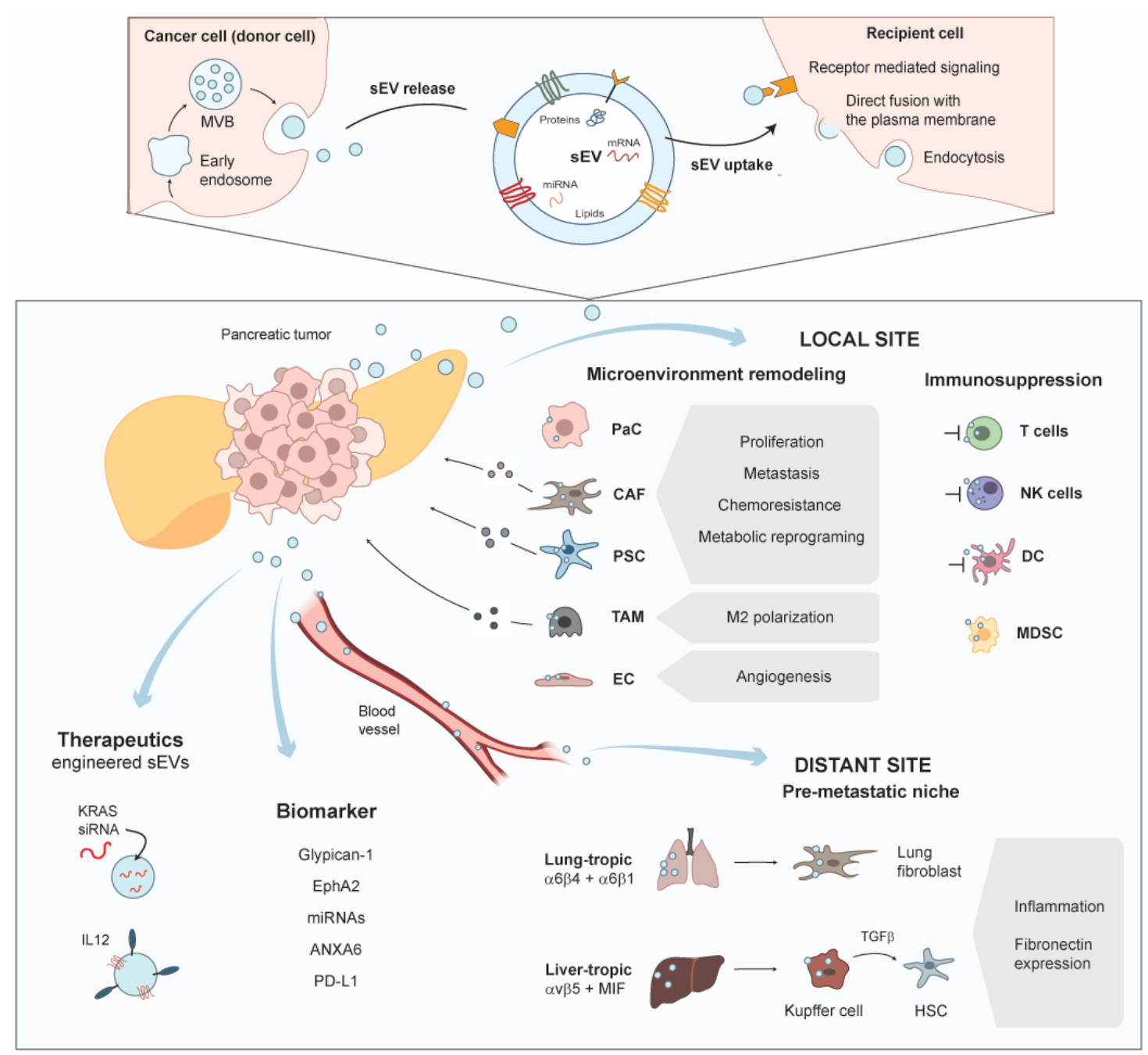

Figure 1. sEVs in short- and long-distance intercellular communication during PDAC initiation, progression, and metastasis.

Author Contributions: Conceptualization, T.S. (Thomas Seufferlein) and T.E.; collection and review of the literature, M.W., T.S. (Tanja Seibold) and T.E.; writing, M.W. and T.E.; review and editing, M.W., T.S. (Thomas Seufferlein) and T.E. All authors have read and agreed to the published version of the manuscript.

Funding: This study was supported by DFG-GRK-2254 (HEIST project no.: 288342734) to Thomas Seufferlein and T.E., as well as DFG project no.: 380319649 (EI792/7-1 and BL-1186/5-1) to T.E. M.W. was funded by a scholarship from the International PhD Programme in Molecular Medicine via the International Graduate School in Molecular Medicine Ulm (IGradU).

Conflicts of Interest: The authors declare no conflict of interest. 


\section{References}

1. Kleeff, J.; Korc, M.; Apte, M.; la Vecchia, C.; Johnson, C.D.; Biankin, A.V.; Neale, R.E.; Tempero, M.; Tuveson, D.A.; Hruban, R.H.; et al. Pancreatic cancer. Nat. Rev. Dis. Primers 2016, 2, 16022. [CrossRef]

2. Orth, M.; Metzger, P.; Gerum, S.; Mayerle, J.; Schneider, G.; Belka, C.; Schnurr, M.; Lauber, K. Pancreatic ductal adenocarcinoma: Biological hallmarks, current status, and future perspectives of combined modality treatment approaches. Radiat. Oncol. 2019, 14, 1-20. [CrossRef]

3. Beel, S.; Kolloch, L.; Apken, L.H.; Jürgens, L.; Bolle, A.; Sudhof, N.; Ghosh, S.; Wardelmann, E.; Meisterernst, M.; Steinestel, K.; et al. KappaB-Ras and Ral GTPases regulate acinar to ductal metaplasia during pancreatic adenocarcinoma development and pancreatitis. Nat. Commun. 2020, 11, 3409. [CrossRef] [PubMed]

4. Storz, P. Acinar cell plasticity and development of pancreatic ductal adenocarcinoma. Nat. Rev. Gastroenterol. Hepatol. 2017, 14, 296-304. [CrossRef]

5. Kamisawa, T.; Wood, L.D.; Itoi, T.; Takaori, K. Pancreatic cancer. Lancet 2016, 388, 73-85. [CrossRef]

6. Buscail, L.; Bournet, B.; Cordelier, P. Role of oncogenic KRAS in the diagnosis, prognosis and treatment of pancreatic cancer. Nat. Rev. Gastroenterol. Hepatol. 2020, 17, 153-168. [CrossRef]

7. Ho, W.J.; Jaffee, E.M.; Zheng, L. The tumour microenvironment in pancreatic cancer-Clinical challenges and opportunities. Nat. Rev. Clin. Oncol. 2020, 17, 527-540. [CrossRef] [PubMed]

8. Karamitopoulou, E. The Tumor Microenvironment of Pancreatic Cancer. Cancers 2020, 12, 3076. [CrossRef]

9. Wendler, F.; Favicchio, R.; Simon, T.; Alifrangis, C.; Stebbing, J.; Giamas, G. Extracellular vesicles swarm the cancer microenvironment: From tumor-stroma communication to drug intervention. Oncogene 2017, 36, 877-884. [CrossRef]

10. Xu, R.; Rai, A.; Chen, M.; Suwakulsiri, W.; Greening, D.W.; Simpson, R.J. Extracellular vesicles in cancer-Implications for future improvements in cancer care. Nat. Rev. Clin. Oncol. 2018, 15, 617-638. [CrossRef]

11. Vennin, C.; Murphy, K.J.; Morton, J.P.; Cox, T.R.; Pajic, M.; Timpson, P. Reshaping the Tumor Stroma for Treatment of Pancreatic Cancer. Gastroenterology 2018, 154, 820-838. [CrossRef]

12. Wang, Q.; Yu, J.; Kadungure, T.; Beyene, J.; Zhang, H.; Lu, Q. ARMMs as a versatile platform for intracellular delivery of macromolecules. Nat. Commun. 2018, 9, 1-7. [CrossRef]

13. Witwer, K.W.; Théry, C. Extracellular vesicles or exosomes? On primacy, precision, and popularity influencing a choice of nomenclature. J. Extracell. Vesicles 2019, 8, 1648167. [CrossRef]

14. Abels, E.R.; Breakefield, X.O. Introduction to Extracellular Vesicles: Biogenesis, RNA Cargo Selection, Content, Release, and Uptake. Cell. Mol. Neurobiol. 2016, 36, 301-312. [CrossRef]

15. Maas, S.L.; Breakefield, X.O.; Weaver, A.M. Extracellular Vesicles: Unique Intercellular Delivery Vehicles. Trends Cell Biol. 2017, 27, 172-188. [CrossRef]

16. Kalluri, R.; LeBleu, V.S. The biology, function, and biomedical applications of exosomes. Science 2020, 367, eaau6977. [CrossRef]

17. Vader, P.; Breakefield, X.O.; Wood, M.J. Extracellular vesicles: Emerging targets for cancer therapy. Trends Mol. Med. 2014, 20, 385-393. [CrossRef]

18. Zhang, Y.; Liu, Y.; Liu, H.; Tang, W.H. Exosomes: Biogenesis, biologic function and clinical potential. Cell Biosci. 2019, 9, 1-18. [CrossRef]

19. Mashouri, L.; Yousefi, H.; Aref, A.R.; Ahadi, A.M.; Molaei, F.; Alahari, S.K. Exosomes: Composition, biogenesis, and mechanisms in cancer metastasis and drug resistance. Mol. Cancer 2019, 18, 1-14. [CrossRef] [PubMed]

20. Kalluri, R. The biology and function of exosomes in cancer. J. Clin. Investig. 2016, 126, 1208-1215. [CrossRef] [PubMed]

21. Van Niel, G.; D'Angelo, G.; Raposo, G. Shedding light on the cell biology of extracellular vesicles. Nat. Rev. Mol. Cell Biol. 2018, 19, 213-228. [CrossRef] [PubMed]

22. Doyle, L.M.; Wang, M.Z. Overview of Extracellular Vesicles, Their Origin, Composition, Purpose, and Methods for Exosome Isolation and Analysis. Cells 2019, 8, 727. [CrossRef]

23. Jankovičová, J.; Sečová, P.; Michalková, K.; Antalíková, J. Tetraspanins, More than Markers of Extracellular Vesicles in Reproduction. Int. J. Mol. Sci. 2020, 21, 7568. [CrossRef]

24. Andreu, Z.; Yanez-Mo, M. Tetraspanins in extracellular vesicle formation and function. Front. Immunol. 2014, 5, 442. [CrossRef]

25. Ni, K.; Wang, C.; Carnino, J.; Jin, Y. The Evolving Role of Caveolin-1: A Critical Regulator of Extracellular Vesicles. Med. Sci. 2020 8, 46. [CrossRef]

26. Yáñez-Mó, M.; Barreiro, O.; Gordon-Alonso, M.; Sala-Valdés, M.; Sánchez-Madrid, F. Tetraspanin-enriched microdomains: A functional unit in cell plasma membranes. Trends Cell Biol. 2009, 19, 434-446. [CrossRef]

27. Greenlee, J.D.; Subramanian, T.; Liu, K.; King, M.R. Rafting Down the Metastatic Cascade: The Role of Lipid Rafts in Cancer Metastasis, Cell Death, and Clinical Outcomes. Cancer Res. 2021, 81, 5-17. [CrossRef]

28. Zaborowski, M.; Balaj, L.; Breakefield, X.O.; Lai, C.P.-K. Extracellular Vesicles: Composition, Biological Relevance, and Methods of Study. BioScience 2015, 65, 783-797. [CrossRef]

29. Zhou, X.; Xie, F.; Wang, L.; Zhang, L.; Zhang, S.; Fang, M.; Zhou, F. The function and clinical application of extracellular vesicles in innate immune regulation. Cell. Mol. Immunol. 2020, 17, 323-334. [CrossRef]

30. LeBleu, V.S.; Kalluri, R. Exosomes as a Multicomponent Biomarker Platform in Cancer. Trends Cancer 2020, 6, 767-774. [CrossRef] [PubMed] 
31. Squadrito, M.L.; Baer, C.; Burdet, F.; Maderna, C.; Gilfillan, G.D.; Lyle, R.; Ibberson, M.; De Palma, M. Endogenous RNAs Modulate MicroRNA Sorting to Exosomes and Transfer to Acceptor Cells. Cell Rep. 2014, 8, 1432-1446. [CrossRef] [PubMed]

32. Tomasetti, M.; Lee, W.; Santarelli, L.; Neuzil, J. Exosome-derived microRNAs in cancer metabolism: Possible implications in cancer diagnostics and therapy. Exp. Mol. Med. 2017, 49, e285. [CrossRef] [PubMed]

33. Pegtel, D.M.; Gould, S.J. Exosomes. Annu. Rev Biochem. 2019, 88, 487-514. [CrossRef]

34. Colombo, M.; Raposo, G.; Thery, C. Biogenesis, secretion, and intercellular interactions of exosomes and other extracellular vesicles. Annu. Rev. Cell Dev. Biol. 2014, 30, 255-289. [CrossRef] [PubMed]

35. Hurley, J.H. The ESCRT complexes. Crit. Rev. Biochem. Mol. Biol. 2010, 45, 463-487. [CrossRef]

36. Meister, M.; Bänfer, S.; Gärtner, U.; Koskimies, J.; Amaddii, M.; Jacob, R.; Tikkanen, R. Regulation of cargo transfer between ESCRT-0 and ESCRT-I complexes by flotillin-1 during endosomal sorting of ubiquitinated cargo. Oncogenesis 2017, 6, e344. [CrossRef]

37. Teis, D.; Saksena, S.; Judson, B.L.; Emr, S.D. ESCRT-II coordinates the assembly of ESCRT-III filaments for cargo sorting and multivesicular body vesicle formation. EMBO J. 2010, 29, 871-883. [CrossRef]

38. Peel, S.; Macheboeuf, P.; Martinelli, N.; Weissenhorn, W. Divergent pathways lead to ESCRT-III-catalyzed membrane fission. Trends Biochem. Sci. 2011, 36, 199-210. [CrossRef]

39. Larios, J.; Mercier, V.; Roux, A.; Gruenberg, J. ALIX- and ESCRT-III-dependent sorting of tetraspanins to exosomes. Cell Biol. 2020, 219. [CrossRef]

40. Tschuschke, M.; Kocherova, I.; Bryja, A.; Mozdziak, P.; Volponi, A.A.; Janowicz, K.; Sibiak, R.; Piotrowska-Kempisty, H.; Iżycki, D.; Bukowska, D.; et al. Inclusion Biogenesis, Methods of Isolation and Clinical Application of Human Cellular Exosomes. J. Clin. Med. 2020, 9, 436. [CrossRef]

41. Middleton, R.C.; Rogers, R.G.; De Couto, G.; Tseliou, E.; Luther, K.; Holewinski, R.; Soetkamp, D.; Van Eyk, J.E.; Antes, T.J.; Marbán, E. Newt cells secrete extracellular vesicles with therapeutic bioactivity in mammalian cardiomyocytes. J. Extracell. Vesicles 2018, 7, 1456888. [CrossRef] [PubMed]

42. Dinkins, M.B.; Dasgupta, S.; Wang, G.; Zhu, G.; Bieberich, E. Exosome reduction in vivo is associated with lower amyloid plaque load in the 5XFAD mouse model of Alzheimer's disease. Neurobiol. Aging 2014, 35, 1792-1800. [CrossRef] [PubMed]

43. Hessvik, N.P.; Llorente, A. Current knowledge on exosome biogenesis and release. Experientia 2018, 75, 193-208. [CrossRef] [PubMed]

44. Di Giaimo, R.; Penna, E.; Pizzella, A.; Cirillo, R.; Perrone-Capano, C.; Crispino, M. Cross Talk at the Cytoskeleton-Plasma Membrane Interface: Impact on Neuronal Morphology and Functions. Int. J. Mol. Sci. 2020, 21, 9133. [CrossRef] [PubMed]

45. Sinha, S.; Hoshino, D.; Hong, N.H.; Kirkbride, K.C.; Grega-Larson, N.E.; Seiki, M.; Tyska, M.J.; Weaver, A.M. Cortactin promotes exosome secretion by controlling branched actin dynamics. J. Cell Biol. 2016, 214, 197-213. [CrossRef]

46. Helgeson, L.A.; Nolen, B.J. Mechanism of synergistic activation of Arp2/3 complex by cortactin and N-WASP. eLife 2013, 2, e00884. [CrossRef]

47. Armacki, M.; Polaschek, S.; Waldenmaier, M.; Morawe, M.; Ruhland, C.; Schmid, R.; Lechel, A.; Tharehalli, U.; Steup, C.; Bektas, Y.; et al. Protein Kinase D1, Reduced in Human Pancreatic Tumors, Increases Secretion of Small Extracellular Vesicles From Cancer Cells That Promote Metastasis to Lung in Mice. Gastroenterology 2020, 159, 1019-1035.e22. [CrossRef]

48. Eiseler, T.; Hausser, A.; De Kimpe, L.; Van Lint, J.; Pfizenmaier, K. Protein kinase D controls actin polymerization and cell motility through phosphorylation of cortactin. J. Biol. Chem. 2010, 285, 18672-18683. [CrossRef]

49. Jia, Y.-C.; Ding, Y.-X.; Mei, W.-T.; Wang, Y.-T.; Zheng, Z.; Qu, Y.-X.; Liang, K.; Li, J.; Cao, F.; Li, F. Extracellular vesicles and pancreatitis: Mechanisms, status and perspectives. Int. J. Biol. Sci. 2021, 17, 549-561. [CrossRef] [PubMed]

50. Lan, B.; Zeng, S.; Grützmann, R.; Pilarsky, C. The Role of Exosomes in Pancreatic Cancer. Int. J. Mol. Sci. 2019, 20, 4332. [CrossRef]

51. Allenson, K.; Castillo, J.; San Lucas, F.A.; Scelo, G.; Kim, D.U.; Bernard, V.; Davis, G.; Kumar, T.; Katz, M.; Overman, M.J.; et al. High prevalence of mutantKRAS in circulating exosome-derived DNA from early-stage pancreatic cancer patients. Ann. Oncol. 2017, 28, 741-747. [CrossRef]

52. Jafari, R.; Rahbarghazi, R.; Ahmadi, M.; Hassanpour, M.; Rezaie, J. Hypoxic exosomes orchestrate tumorigenesis: Molecular mechanisms and therapeutic implications. J. Transl. Med. 2020, 18, 1-14. [CrossRef] [PubMed]

53. Parolini, I.; Federici, C.; Raggi, C.; Lugini, L.; Palleschi, S.; De Milito, A.; Coscia, C.; Iessi, E.; Logozzi, M.; Molinari, A.; et al. Microenvironmental pH Is a Key Factor for Exosome Traffic in Tumor Cells. J. Biol. Chem. 2009, 284, 34211-34222. [CrossRef]

54. Patton, M.C.; Zubair, H.; Khan, M.A.; Singh, S.; Singh, A.P. Hypoxia alters the release and size distribution of extracellular vesicles in pancreatic cancer cells to support their adaptive survival. J. Cell. Biochem. 2020, 121, 828-839. [CrossRef]

55. Kilinc, S.; Paisner, R.; Camarda, R.; Gupta, S.; Momcilovic, O.; Kohnz, R.A.; Avsaroglu, B.; L'Etoile, N.D.; Perera, R.M.; Nomura, D.K.; et al. Oncogene-regulated release of extracellular vesicles. Dev. Cell 2021, 56, 1989-2006.e6. [CrossRef]

56. Lee, T.H.; Chennakrishnaiah, S.; Audemard, E.; Montermini, L.; Meehan, B.; Rak, J. Oncogenic ras-driven cancer cell vesiculation leads to emission of double-stranded DNA capable of interacting with target cells. Biochem. Biophys. Res. Commun. 2014, 451, 295-301. [CrossRef]

57. Lee, T.H.; Chennakrishnaiah, S.; Meehan, B.; Montermini, L.; Garnier, D.; D'Asti, E.; Hou, W.; Magnus, N.; Gayden, T.; Jabado, N.; et al. Barriers to horizontal cell transformation by extracellular vesicles containing oncogenic H-ras. Oncotarget 2016, 7, 51991-52002. [CrossRef] 
58. Beckler, M.D.; Higginbotham, J.N.; Franklin, J.L.; Ham, A.-J.; Halvey, P.J.; Imasuen, I.E.; Whitwell, C.; Li, M.; Liebler, D.C.; Coffey, R.J. Proteomic Analysis of Exosomes from Mutant KRAS Colon Cancer Cells Identifies Intercellular Transfer of Mutant KRAS. Mol. Cell. Proteom. 2013, 12, 343-355. [CrossRef]

59. Cha, D.J.; Franklin, J.L.; Dou, Y.; Liu, Q.; Higginbotham, J.N.; Beckler, M.D.; Weaver, A.M.; Vickers, K.; Prasad, N.; Levy, S.; et al. KRAS-dependent sorting of miRNA to exosomes. eLife 2015, 4, e07197. [CrossRef] [PubMed]

60. Zhang, Q.; Jeppesen, D.K.; Higginbotham, J.N.; Beckler, M.D.; Poulin, E.J.; Walsh, A.J.; Skala, M.C.; McKinley, E.T.; Manning, H.C.; Hight, M.R.; et al. Mutant KRAS Exosomes Alter the Metabolic State of Recipient Colonic Epithelial Cells. Cell. Mol. Gastroenterol. Hepatol. 2018, 5, 627-629.e6. [CrossRef] [PubMed]

61. Tran, N. Cancer Exosomes as miRNA Factories. Trends Cancer 2016, 2, 329-331. [CrossRef]

62. Kahlert, C.; Melo, S.A.; Protopopov, A.; Tang, J.; Seth, S.; Koch, M.; Zhang, J.; Weitz, J.; Chin, L.; Futreal, A.; et al. Identification of Double-stranded Genomic DNA Spanning All Chromosomes with Mutated KRAS and p53 DNA in the Serum Exosomes of Patients with Pancreatic Cancer. J. Biol. Chem. 2014, 289, 3869-3875. [CrossRef] [PubMed]

63. Eser, S.; Schnieke, A.; Schneider, G.; Saur, D. Oncogenic KRAS signalling in pancreatic cancer. Br. J. Cancer 2014, 111, 817-822. [CrossRef]

64. McGuigan, A.; Kelly, P.; Turkington, R.C.; Jones, C.; Coleman, H.G.; McCain, R.S. Pancreatic cancer: A review of clinical diagnosis, epidemiology, treatment and outcomes. World J. Gastroenterol. 2018, 24, 4846-4861. [CrossRef] [PubMed]

65. Yadav, D.; Lowenfels, A.B. The Epidemiology of Pancreatitis and Pancreatic Cancer. Gastroenterology 2013, $144,1252-1261$. [CrossRef] [PubMed]

66. Kirkegård, J.; Cronin-Fenton, D.; Heide-Jørgensen, U.; Mortensen, F.V. Acute Pancreatitis and Pancreatic Cancer Risk: A Nationwide Matched-Cohort Study in Denmark. Gastroenterology 2018, 154, 1729-1736. [CrossRef]

67. Kirkegård, J.; Mortensen, F.V.; Cronin-Fenton, D. Chronic Pancreatitis and Pancreatic Cancer Risk: A Systematic Review and Meta-analysis. Am. J. Gastroenterol. 2017, 112, 1366-1372. [CrossRef]

68. Beyer, G.; Habtezion, A.; Werner, J.; Lerch, M.M.; Mayerle, J. Chronic pancreatitis. Lancet 2020, 396, 499-512. [CrossRef]

69. Romano, R.; Picca, A.; Eusebi, L.H.U.; Marzetti, E.; Calvani, R.; Moro, L.; Bucci, C.; Guerra, F. Extracellular Vesicles and Pancreatic Cancer: Insights on the Roles of miRNA, lncRNA, and Protein Cargos in Cancer Progression. Cells 2021, 10, 1361. [CrossRef]

70. Bonjoch, L.; Casas, V.; Carrascal, M.; Closa, D. Involvement of exosomes in lung inflammation associated with experimental acute pancreatitis. J. Pathol. 2016, 240, 235-245. [CrossRef]

71. Jiménez-Alesanco, A.; Marcuello, M.; Pastor-Jiménez, M.; López-Puerto, L.; Bonjoch, L.; Gironella, M.; Carrascal, M.; Abian, J.; De-Madaria, E.; Closa, D. Acute pancreatitis promotes the generation of two different exosome populations. Sci. Rep. 2019, 9, 1-13. [CrossRef]

72. Kleeff, J.; Whitcomb, D.C.; Shimosegawa, T.; Esposito, I.; Lerch, M.M.; Gress, T.; Mayerle, J.; Mohr Drewes, A.; Rebours, V.; Akisik, F.; et al. Chronic pancreatitis. Nat. Rev. Dis. Primers 2017, 3, 17060. [CrossRef] [PubMed]

73. Lesina, M.; Kurkowski, M.U.; Ludes, K.; Rose-John, S.; Treiber, M.; Klöppel, G.; Yoshimura, A.; Reindl, W.; Sipos, B.; Akira, S.; et al. Stat3/Socs3 Activation by IL-6 Transsignaling Promotes Progression of Pancreatic Intraepithelial Neoplasia and Development of Pancreatic Cancer. Cancer Cell 2011, 19, 456-469. [CrossRef]

74. Nagathihalli, N.S.; Castellanos, J.A.; VanSaun, M.N.; Dai, X.; Ambrose, M.; Guo, Q.; Xiong, Y.; Merchant, N.B. Pancreatic stellate cell secreted IL-6 stimulates STAT3 dependent invasiveness of pancreatic intraepithelial neoplasia and cancer cells. Oncotarget 2016, 7, 65982-65992. [CrossRef]

75. Charrier, A.L.; Brigstock, D.R. Connective tissue growth factor production by activated pancreatic stellate cells in mouse alcoholic chronic pancreatitis. Lab. Investig. 2010, 90, 1179-1188. [CrossRef] [PubMed]

76. Charrier, A.; Chen, R.; Chen, L.; Kemper, S.; Hattori, T.; Takigawa, M.; Brigstock, D.R. Connective tissue growth factor (CCN2) and microRNA-21 are components of a positive feedback loop in pancreatic stellate cells (PSC) during chronic pancreatitis and are exported in PSC-derived exosomes. J. Cell Commun. Signal. 2014, 8, 147-156. [CrossRef] [PubMed]

77. Dougan, S.K. The Pancreatic Cancer Microenvironment. Cancer J. 2017, 23, 321-325. [CrossRef] [PubMed]

78. Rucki, A.A.; Foley, K.; Zhang, P.; Xiao, Q.; Kleponis, J.; Wu, A.A.; Sharma, R.; Mo, G.; Liu, A.; Van Eyk, J.; et al. Heterogeneous Stromal Signaling within the Tumor Microenvironment Controls the Metastasis of Pancreatic Cancer. Cancer Res. 2017, 77, 41-52. [CrossRef] [PubMed]

79. Dai, J.; Su, Y.; Zhong, S.; Cong, L.; Liu, B.; Yang, J.; Tao, Y.; He, Z.; Chen, C.; Jiang, Y. Exosomes: Key players in cancer and potential therapeutic strategy. Signal Transduct. Target. Ther. 2020, 5, 1-10. [CrossRef] [PubMed]

80. De Jaeghere, E.A.; Denys, H.G.; De Wever, O. Fibroblasts Fuel Immune Escape in the Tumor Microenvironment. Trends Cancer 2019, 5, 704-723. [CrossRef]

81. Procacci, P.; Moscheni, C.; Sartori, P.; Sommariva, M.; Gagliano, N. Tumor-Stroma Cross-Talk in Human Pancreatic Ductal Adenocarcinoma: A Focus on the Effect of the Extracellular Matrix on Tumor Cell Phenotype and Invasive Potential. Cells 2018, 7, 158. [CrossRef]

82. Thomas, S.; Lee, J.; Beatty, G.L. Paracrine and cell autonomous signalling in pancreatic cancer progression and metastasis. EBioMedicine 2020, 53, 102662. [CrossRef] [PubMed]

83. Murphy, K.; Chambers, C.R.; Herrmann, D.; Timpson, P.; Pereira, B.A. Dynamic Stromal Alterations Influence Tumor-Stroma Crosstalk to Promote Pancreatic Cancer and Treatment Resistance. Cancers 2021, 13, 3481. [CrossRef] 
84. Sperb, N.; Tsesmelis, M.; Wirth, T. Crosstalk between Tumor and Stromal Cells in Pancreatic Ductal Adenocarcinoma. Int. J. Mol. Sci. 2020, 21, 5486. [CrossRef] [PubMed]

85. Pereira, S.P.; Oldfield, L.; Ney, A.; Hart, P.A.; Keane, M.G.; Pandol, S.J.; Li, D.; Greenhalf, W.; Leon, C.Y.; Koay, E.J.; et al. Early detection of pancreatic cancer. Lancet Gastroenterol. Hepatol. 2020, 5, 698-710. [CrossRef]

86. Whiteside, T.L. Tumor-Derived Exosomes and Their Role in Cancer Progression. Adv. Clin. Chem. 2016, 74, 103-141. [CrossRef]

87. Yang, E.; Wang, X.; Gong, Z.; Yu, M.; Wu, H.; Zhang, D. Exosome-mediated metabolic reprogramming: The emerging role in tumor microenvironment remodeling and its influence on cancer progression. Signal Transduct. Target. Ther. 2020, 5, 1-13. [CrossRef] [PubMed]

88. Ligorio, M.; Sil, S.; Malagon-Lopez, J.; Nieman, L.T.; Misale, S.; Di Pilato, M.; Ebright, R.Y.; Karabacak, N.M.; Kulkarni, A.S.; Liu, A.; et al. Stromal Microenvironment Shapes the Intratumoral Architecture of Pancreatic Cancer. Cell 2019, 178, 160-175.e27. [CrossRef] [PubMed]

89. Bernauer, C.; Man, Y.K.S.; Chisholm, J.C.; Lepicard, E.Y.; Robinson, S.P.; Shipley, J.M. Hypoxia and its therapeutic possibilities in paediatric cancers. Br. J. Cancer 2020, 124, 539-551. [CrossRef]

90. Wang, X.; Luo, G.; Zhang, K.; Cao, J.; Huang, C.; Jiang, T.; Liu, B.; Su, L.; Qiu, Z. Hypoxic Tumor-Derived Exosomal miR-301a Mediates M2 Macrophage Polarization via PTEN/PI3Kgamma to Promote Pancreatic Cancer Metastasis. Cancer Res 2018, 78, 4586-4598. [CrossRef]

91. Zhao, H.; Yang, L.; Baddour, J.; Achreja, A.; Bernard, V.; Moss, T.; Marini, J.C.; Tudawe, T.; Seviour, E.G.; San Lucas, F.A.; et al. Tumor microenvironment derived exosomes pleiotropically modulate cancer cell metabolism. eLife 2016, 5, e10250. [CrossRef]

92. Achreja, A.; Zhao, H.; Yang, L.; Yun, T.H.; Marini, J.; Nagrath, D. Exo-MFA-A 13C metabolic flux analysis framework to dissect tumor microenvironment-secreted exosome contributions towards cancer cell metabolism. Metab. Eng. 2017, 43, 156-172. [CrossRef] [PubMed]

93. Bynigeri, R.R.; Jakkampudi, A.; Jangala, R.; Subramanyam, C.; Sasikala, M.; Rao, G.V.; Reddy, D.N.; Talukdar, R. Pancreatic stellate cell: Pandora's box for pancreatic disease biology. World J. Gastroenterol. 2017, 23, 382-405. [CrossRef] [PubMed]

94. Wu, Y.; Zhang, C.; Jiang, K.; Werner, J.; Bazhin, A.V.; D'Haese, J.G. The Role of Stellate Cells in Pancreatic Ductal Adenocarcinoma: Targeting Perspectives. Front. Oncol. 2021, 10, 1-16. [CrossRef] [PubMed]

95. Schnittert, J.; Bansal, R.; Prakash, J. Targeting Pancreatic Stellate Cells in Cancer. Trends Cancer 2019, 5, 128-142. [CrossRef] [PubMed]

96. Kusiak, A.A.; Szopa, M.D.; Jakubowska, M.A.; Ferdek, P.E. Signaling in the Physiology and Pathophysiology of Pancreatic Stellate Cells-A Brief Review of Recent Advances. Front. Physiol. 2020, 11, 78. [CrossRef]

97. Marzoq, A.J.; Mustafa, S.A.; Heidrich, L.; Hoheisel, J.D.; Alhamdani, M.S.S. Impact of the secretome of activated pancreatic stellate cells on growth and differentiation of pancreatic tumour cells. Sci. Rep. 2019, 9, 1-16. [CrossRef]

98. Lugea, A.; Waldron, R.T. Exosome-Mediated Intercellular Communication between Stellate Cells and Cancer Cells in Pancreatic Ductal Adenocarcinoma. Pancreas 2017, 46, 1-4. [CrossRef]

99. Masamune, A.; Yoshida, N.; Hamada, S.; Takikawa, T.; Nabeshima, T.; Shimosegawa, T. Exosomes derived from pancreatic cancer cells induce activation and profibrogenic activities in pancreatic stellate cells. Biochem. Biophys. Res. Commun. 2018, 495, 71-77. [CrossRef]

100. Takikawa, T.; Masamune, A.; Takikawa, T.; Hamada, S.; Kogure, T.; Nakano, E.; Shimosegawa, T. 258 Exosomes Derived from Pancreatic Stellate Cells: microRNA Signature and Effects on Pancreatic Cancer Cells. Gastroenterology 2017, 46, 19-27. [CrossRef]

101. Li, M.; Guo, H.; Wang, Q.; Chen, K.; Marko, K.; Tian, X.; Yang, Y. Pancreatic stellate cells derived exosomal miR-5703 promotes pancreatic cancer by downregulating CMTM4 and activating PI3K/Akt pathway. Cancer Lett. 2020, 490, 20-30. [CrossRef]

102. Zanotelli, M.R.; Reinhart-King, C.A. Mechanical Forces in Tumor Angiogenesis. Adv. Exp. Med. Biol. 2018, 1092, 91-112.

103. van der Zee, J.A.; van Eijck, C.H.J.; Hop, W.C.J.; van Dekken, H.; Dicheva, B.M.; Seynhaeve, A.L.B.; Koning, G.A.; Eggermont, A.M.M.; ten Hagen, T.L.M. Angiogenesis: A prognostic determinant in pancreatic cancer? Eur. J. Cancer 2011, 47, 2576-2584. [CrossRef]

104. Barău, A.; Ruiz-Sauri, A.; Valencia, G.; Gómez-Mateo, M.D.C.; Sabater, L.; Ferrandez, A.; Llombart-Bosch, A. High microvessel density in pancreatic ductal adenocarcinoma is associated with high grade. Virchows. Arch. 2013, 462, 541-546. [CrossRef]

105. Wang, W.-Q.; Liu, L.; Xu, H.-X.; Luo, G.-P.; Chen, T.; Wu, C.-T.; Xu, Y.-F.; Xu, J.; Liu, C.; Zhang, B.; et al. Intratumoral $\alpha$-SMA Enhances the Prognostic Potency of CD34 Associated with Maintenance of Microvessel Integrity in Hepatocellular Carcinoma and Pancreatic Cancer. PLoS ONE 2013, 8, e71189. [CrossRef]

106. Olejarz, W.; Kubiak-Tomaszewska, G.; Chrzanowska, A.; Lorenc, T. Exosomes in Angiogenesis and Anti-angiogenic Therapy in Cancers. Int. J. Mol. Sci. 2020, 21, 5840. [CrossRef]

107. Nazarenko, I.; Rana, S.; Baumann, A.; McAlear, J.; Hellwig, A.; Trendelenburg, M.; Lochnit, G.; Preissner, K.T.; Zöller, M. Cell Surface Tetraspanin Tspan8 Contributes to Molecular Pathways of Exosome-Induced Endothelial Cell Activation. Cancer Res. 2010, 70, 1668-1678. [CrossRef]

108. Wang, C.; Chang, I.; Hou, P.; Tai, Y.; Li, W.; Hsu, P.; Wu, S.; Chiu, W.; Li, C.; Shan, Y.; et al. DUSP2 regulates extracellular vesicle-VEGF-C secretion and pancreatic cancer early dissemination. J. Extracell. Vesicles 2020, 9, 1746529. [CrossRef]

109. Bellido, D.D.; Serrano-Saenz, S.; Fernández-Cortés, M.; Oliver, F.J. Vasculogenic mimicry signaling revisited: Focus on nonvascular VE-cadherin. Mol. Cancer 2017, 16, 1-14. [CrossRef] 
110. Liang, K.; Liu, F.; Fan, J.; Sun, D.; Liu, C.; Lyon, C.J.; Bernard, D.W.; Li, Y.; Yokoi, K.; Katz, M.H.; et al. Nanoplasmonic Quantification of Tumor-derived Extracellular Vesicles in Plasma Microsamples for Diagnosis and Treatment Monitoring. Nat. Biomed. Eng. 2017, 1, 21. [CrossRef]

111. Batista, I.A.; Melo, S.A. Exosomes and the Future of Immunotherapy in Pancreatic Cancer. Int. J. Mol. Sci. 2019, 20, 567. [CrossRef]

112. Egen, J.G.; Ouyang, W.; Wu, L.C. Human Anti-tumor Immunity: Insights from Immunotherapy Clinical Trials. Immunity 2020, 52, 36-54. [CrossRef] [PubMed]

113. Huber, M.; Brehm, C.U.; Gress, T.M.; Buchholz, M.; Alhamwe, B.A.; Von Strandmann, E.P.; Slater, E.P.; Bartsch, J.W.; Bauer, C.; Lauth, M. The Immune Microenvironment in Pancreatic Cancer. Int. J. Mol. Sci. 2020, 21, 7307. [CrossRef] [PubMed]

114. Saka, D.; Gökalp, M.; Piyade, B.; Cevik, N.C.; Sever, E.A.; Unutmaz, D.; Ceyhan, G.O.; Demir, I.E.; Asimgil, H. Mechanisms of T-Cell Exhaustion in Pancreatic Cancer. Cancer 2020, 12, 2274. [CrossRef] [PubMed]

115. Czernek, L.; Düchler, M. Functions of Cancer-Derived Extracellular Vesicles in Immunosuppression. Arch. Immunol. Ther. Exp. 2017, 65, 311-323. [CrossRef]

116. Xiang, X.; Wang, J.; Lu, D.; Xu, X. Targeting tumor-associated macrophages to synergize tumor immunotherapy. Signal Transduct Target. Ther. 2021, 6, 1-12. [CrossRef]

117. Pathria, P.; Louis, T.L.; Varner, J.A. Targeting Tumor-Associated Macrophages in Cancer. Trends Immunol. 2019, 40, 310-327. [CrossRef]

118. Cendrowicz, E.; Sas, Z.; Bremer, E.; Rygiel, T.P. The Role of Macrophages in Cancer Development and Therapy. Cancers 2021, $13,1946$. [CrossRef]

119. Zhou, J.; Tang, Z.; Gao, S.; Li, C.; Feng, Y.; Zhou, X. Tumor-Associated Macrophages: Recent Insights and Therapies. Front. Oncol. 2020, 10, 188. [CrossRef]

120. Yang, S.; Liu, Q.; Liao, Q. Tumor-Associated Macrophages in Pancreatic Ductal Adenocarcinoma: Origin, Polarization, Function, and Reprogramming. Front. Cell Dev. Biol. 2021, 8, 1-24. [CrossRef]

121. Baig, M.S.; Roy, A.; Rajpoot, S.; Liu, D.; Savai, R.; Banerjee, S.; Kawada, M.; Faisal, S.M.; Saluja, R.; Saqib, U.; et al. Tumor-derived exosomes in the regulation of macrophage polarization. Inflamm. Res. 2020, 69, 435-451. [CrossRef]

122. Lin, Y.; Xu, J.; Lan, H. Tumor-associated macrophages in tumor metastasis: Biological roles and clinical therapeutic applications. $J$. Hematol. Oncol. 2019, 12,1-16. [CrossRef]

123. Linton, S.S.; Abraham, T.; Liao, J.; Clawson, G.A.; Butler, P.J.; Fox, T.; Kester, M.; Matters, G.L. Tumor-promoting effects of pancreatic cancer cell exosomes on THP-1-derived macrophages. PLoS ONE 2018, 13, e0206759. [CrossRef] [PubMed]

124. Chang, Y.-T.; Peng, H.-Y.; Hu, C.-M.; Huang, S.-C.; Tien, S.-C.; Jeng, Y.-M. Pancreatic cancer-derived small extracellular vesical Ezrin regulates macrophage polarization and promotes metastasis. Am. J. Cancer Res. 2020, 10, 12-37. [PubMed]

125. Yin, Z.; Ma, T.; Huang, B.; Lin, L.; Zhou, Y.; Yan, J.; Zou, Y.; Chen, S. Macrophage-derived exosomal microRNA-501-3p promotes progression of pancreatic ductal adenocarcinoma through the TGFBR3-mediated TGF-beta signaling pathway. J. Exp. Clin. Cancer Res. 2019, 38, 310. [CrossRef] [PubMed]

126. Yang, Y.; Guo, Z.; Chen, W.; Wang, X.; Cao, M.; Han, X.; Zhang, K.; Teng, B.; Cao, J.; Wu, W.; et al. M2 Macrophage-Derived Exosomes Promote Angiogenesis and Growth of Pancreatic Ductal Adenocarcinoma by Targeting E2F2. Mol. Ther. 2020, 29, 1226-1238. [CrossRef]

127. Li, X.; Xu, H.; Yi, J.; Dong, C.; Zhang, H.; Wang, Z.; Miao, L.; Zhou, W. miR-365 secreted from M2 Macrophage-derived extracellular vesicles promotes pancreatic ductal adenocarcinoma progression through the BTG2/FAK/AKT axis. J. Cell. Mol. Med. 2021, 25, 4671-4683. [CrossRef]

128. Pergamo, M.; Miller, G. Myeloid-derived suppressor cells and their role in pancreatic cancer. Cancer Gene Ther. 2017, 24, 100-105. [CrossRef] [PubMed]

129. Veglia, F.; Sanseviero, E.; Gabrilovich, D.I. Myeloid-derived suppressor cells in the era of increasing myeloid cell diversity. Nat. Rev. Immunol. 2021, 21, 485-498. [CrossRef] [PubMed]

130. Trovato, R.; Fiore, A.; Sartori, S.; Canè, S.; Giugno, R.; Cascione, L.; Paiella, S.; Salvia, R.; De Sanctis, F.; Poffe, O.; et al. Immunosuppression by monocytic myeloid-derived suppressor cells in patients with pancreatic ductal carcinoma is orchestrated by STAT3. J. Immunother. Cancer 2019, 7, 255. [CrossRef]

131. Ostrand-Rosenberg, S. Myeloid-Derived Suppressor Cells: Facilitators of Cancer and Obesity-Induced Cancer. Annu. Rev. Cancer Biol. 2021, 5, 17-38. [CrossRef]

132. Yang, Y.; Li, C.; Liu, T.; Dai, X.; Bazhin, A.V. Myeloid-Derived Suppressor Cells in Tumors: From Mechanisms to Antigen Specificity and Microenvironmental Regulation. Front. Immunol. 2020, 11, 1371. [CrossRef] [PubMed]

133. Corzo, C.A.; Condamine, T.; Lu, L.; Cotter, M.J.; Youn, J.-I.; Cheng, P.; Cho, H.-I.; Celis, E.; Quiceno, D.G.; Padhya, T.; et al. HIF-1 $\alpha$ regulates function and differentiation of myeloid-derived suppressor cells in the tumor microenvironment. J. Exp. Med. 2010, 207, 2439-2453. [CrossRef] [PubMed]

134. Kumar, V.; Patel, S.; Tcyganov, E.; Gabrilovich, D.I. The Nature of Myeloid-Derived Suppressor Cells in the Tumor Microenvironment. Trends Immunol. 2016, 37, 208-220. [CrossRef] [PubMed]

135. Basso, D.; Gnatta, E.; Padoan, A.; Fogar, P.; Furlanello, S.; Aita, A.; Bozzato, D.; Zambon, C.-F.; Arrigoni, G.; Frasson, C.; et al. PDAC-derived exosomes enrich the microenvironment in MDSCs in a SMAD4-dependent manner through a new calcium related axis. Oncotarget 2017, 8, 84928-84944. [CrossRef] [PubMed] 
136. Deicher, A.; Andersson, R.; Tingstedt, B.; Lindell, G.; Bauden, M.; Ansari, D. Targeting dendritic cells in pancreatic ductal adenocarcinoma. Cancer Cell Int. 2018, 18, 85. [CrossRef] [PubMed]

137. Gardner, A.; Ruffell, B. Dendritic Cells and Cancer Immunity. Trends Immunol. 2016, 37, 855-865. [CrossRef] [PubMed]

138. Wculek, S.K.; Cueto, F.J.; Mujal, A.M.; Melero, I.; Krummel, M.F.; Sancho, D. Dendritic cells in cancer immunology and immunotherapy. Nat. Rev. Immunol. 2019, 20, 7-24. [CrossRef] [PubMed]

139. Hosseini, R.; Asef-Kabiri, L.; Yousefi, H.; Sarvnaz, H.; Salehi, M.; Akbari, M.E.; Eskandari, N. The roles of tumor-derived exosomes in altered differentiation, maturation and function of dendritic cells. Mol. Cancer 2021, 20, 1-17. [CrossRef] [PubMed]

140. Zhou, M.; Chen, J.; Zhou, L.; Chen, W.; Ding, G.; Cao, L. Pancreatic cancer derived exosomes regulate the expression of TLR4 in dendritic cells via miR-203. Cell. Immunol. 2014, 292, 65-69. [CrossRef]

141. Ding, G.; Zhou, L.; Qian, Y.; Fu, M.; Chen, J.; Chen, J.; Xiang, J.; Wu, Z.; Jiang, G.; Cao, L. Pancreatic cancer-derived exosomes transfer miRNAs to dendritic cells and inhibit RFXAP expression via miR-212-3p. Oncotarget 2015, 6, 29877-29888. [CrossRef]

142. Zech, D.; Rana, S.; Büchler, M.W.; Zöller, M. Tumor-exosomes and leukocyte activation: An ambivalent crosstalk. Cell Commun. Signal. 2012, 10, 37. [CrossRef]

143. Togashi, Y.; Shitara, K.; Nishikawa, H. Regulatory T cells in cancer immunosuppression-implications for anticancer therapy. Nat. Rev. Clin. Oncol. 2019, 16, 356-371. [CrossRef] [PubMed]

144. Zou, W. Regulatory T cells, tumour immunity and immunotherapy. Nat. Rev. Immunol. 2006, 6, 295-307. [CrossRef] [PubMed]

145. Cinier, J.; Hubert, M.; Besson, L.; Di Roio, A.; Rodriguez, C.; Lombardi, V.; Caux, C.; Ménétrier-Caux, C. Recruitment and Expansion of Tregs Cells in the Tumor Environment-How to Target Them? Cancers 2021, 13, 1850. [CrossRef]

146. Shen, T.; Jia, S.; Ding, G.; Ping, D.; Zhou, L.; Zhou, S.; Cao, L. BxPC-3-Derived Small Extracellular Vesicles Induce FOXP3+ Treg through ATM-AMPK-Sirtuins-Mediated FOXOs Nuclear Translocations. iScience 2020, 23, 101431. [CrossRef]

147. Peinado, H.; Zhang, H.; Matei, I.R.; Costa-Silva, B.; Hoshino, A.; Rodrigues, G.; Psaila, B.; Kaplan, R.N.; Bromberg, J.F.; Kang, Y.; et al. Pre-metastatic niches: Organ-specific homes for metastases. Nat. Rev. Cancer 2017, 17, 302-317. [CrossRef]

148. Hamidi, H.; Ivaska, J. Every step of the way: Integrins in cancer progression and metastasis. Nat. Rev. Cancer 2018, 18, 533-548. [CrossRef]

149. Cooper, J.; Giancotti, F.G. Integrin Signaling in Cancer: Mechanotransduction, Stemness, Epithelial Plasticity, and Therapeutic Resistance. Cancer Cell 2019, 35, 347-367. [CrossRef]

150. Soung, Y.H.; Ford, S.; Yan, C.; Chung, J. Roles of integrins in regulating metastatic potentials of cancer cell derived exosomes. Mol. Cell. Toxicol. 2019, 15, 233-237. [CrossRef]

151. Nolte, M.A.; Hoen, E.N.N.; Margadant, C. Integrins Control Vesicular Trafficking; New Tricks for Old Dogs. Trends Biochem. Sci. 2020, 46, 124-137. [CrossRef] [PubMed]

152. Soe, Z.; Park, E.; Shimaoka, M. Integrin Regulation in Immunological and Cancerous Cells and Exosomes. Int. J. Mol. Sci. 2021, 22, 2193. [CrossRef] [PubMed]

153. Costa-Silva, B.; Aiello, N.; Ocean, A.J.; Singh, S.; Zhang, H.; Thakur, B.K.; Becker, A.; Hoshino, A.; Mark, M.T.; Molina, H.; et al. Pancreatic cancer exosomes initiate pre-metastatic niche formation in the liver. Nature 2015, 17, 816-826. [CrossRef]

154. Hoshino, A.; Costa-Silva, B.; Shen, T.-L.; Rodrigues, G.; Hashimoto, A.; Mark, M.T.; Molina, H.; Kohsaka, S.; Di Giannatale, A.; Ceder, S.; et al. Tumour exosome integrins determine organotropic metastasis. Nature 2015, 527, 329-335. [CrossRef]

155. Yang, J.; Weinberg, R.A. Epithelial-Mesenchymal Transition: At the Crossroads of Development and Tumor Metastasis. Dev. Cell 2008, 14, 818-829. [CrossRef]

156. Dudas, J. Supportive and rejective functions of tumor stroma on tumor cell growth, survival, and invasivity: The cancer evolution. Front. Oncol. 2015, 5, 44. [CrossRef]

157. Cano, A.; Pérez-Moreno, M.A.; Rodrigo, I.; Locascio, A.; Blanco, M.J.; Del Barrio, M.G.; Portillo, F.; Nieto, M.A. The transcription factor Snail controls epithelial-mesenchymal transitions by repressing E-cadherin expression. Nature 2000, 2, 76-83. [CrossRef]

158. Medici, D.; Hay, E.D.; Olsen, B.R. Snail and Slug promote epithelial-mesenchymal transition through beta-catenin-T-cell factor-4dependent expression of transforming growth factor-beta3. Mol. Biol. Cell 2008, 19, 4875-4887. [CrossRef]

159. Peinado, H.; Olmeda, D.; Cano, A. Snail, Zeb and bHLH factors in tumour progression: An alliance against the epithelial phenotype? Nat. Rev. Cancer 2007, 7, 415-428. [CrossRef]

160. Thiery, J.P. Epithelial-mesenchymal transitions in tumour progression. Nat. Rev. Cancer 2002, 2, 442-454. [CrossRef]

161. Qian, S.; Tan, X.; Liu, X.; Liu, P.; Wu, Y. Exosomal Tenascin-c induces proliferation and invasion of pancreatic cancer cells by WNT signaling. OncoTargets Ther. 2019, 12, 3197-3205. [CrossRef]

162. Zhang, Y.-F.; Zhou, Y.-Z.; Zhang, B.; Huang, S.-F.; Li, P.-P.; He, X.-M.; Cao, G.-D.; Kang, M.-X.; Dong, X.; Wu, Y.-L. Pancreatic cancer-derived exosomes promoted pancreatic stellate cells recruitment by pancreatic cancer. J. Cancer 2019, 10, 4397-4407. [CrossRef]

163. Guo, Y.; Ji, X.; Liu, J.; Fan, D.; Zhou, Q.; Chen, C.; Wang, W.; Wang, G.; Wang, H.; Yuan, W.; et al. Effects of exosomes on pre-metastatic niche formation in tumors. Mol. Cancer 2019, 18, 1-11. [CrossRef]

164. Grossberg, A.J.; Chu, L.C.; Deig, C.R.; Fishman, E.K.; Hwang, W.L.; Maitra, A.; Marks, D.L.; Mehta, A.; Nabavizadeh, N.; Simeone, D.M.; et al. Multidisciplinary standards of care and recent progress in pancreatic ductal adenocarcinoma. CA A Cancer J. Clin. 2020, 70. [CrossRef]

165. Vasan, N.; Baselga, J.; Hyman, D.M. A view on drug resistance in cancer. Nature 2019, 575, 299-309. [CrossRef] 
166. Zeng, S.; Pöttler, M.; Lan, B.; Grützmann, R.; Pilarsky, C.; Yang, H. Chemoresistance in Pancreatic Cancer. Int. J. Mol. Sci. 2019, 20, 4504. [CrossRef]

167. Yang, Z.; Zhao, N.; Cui, J.; Wu, H.; Xiong, J.; Peng, T. Exosomes derived from cancer stem cells of gemcitabine-resistant pancreatic cancer cells enhance drug resistance by delivering miR-210. Cell. Oncol. 2019, 43, 123-136. [CrossRef]

168. Mikamori, M.; Yamada, D.; Eguchi, H.; Hasegawa, S.; Kishimoto, T.; Tomimaru, Y.; Asaoka, T.; Noda, T.; Wada, H.; Kawamoto, K.; et al. MicroRNA-155 Controls Exosome Synthesis and Promotes Gemcitabine Resistance in Pancreatic Ductal Adenocarcinoma. Sci. Rep. 2017, 7, 42339. [CrossRef]

169. Patel, G.K.; Khan, M.A.; Bhardwaj, A.; Srivastava, S.K.; Zubair, H.; Patton, M.C.; Singh, S.; Khushman, M.; Singh, A. Exosomes confer chemoresistance to pancreatic cancer cells by promoting ROS detoxification and miR-155-mediated suppression of key gemcitabine-metabolising enzyme, DCK. Br. J. Cancer 2017, 116, 609-619. [CrossRef]

170. Wang, N.; Ma, J.; Ren, Y.; Xiang, S.; Jia, R. Secreted klotho from exosomes alleviates inflammation and apoptosis in acute pancreatitis. Am. J. Transl. Res. 2019, 11, 3375-3383.

171. Yue, S.; Mu, W.; Erb, U.; Zöller, M. The tetraspanins CD151 and Tspan8 are essential exosome components for the crosstalk between cancer initiating cells and their surrounding. Oncotarget 2015, 6, 2366-2384. [CrossRef] [PubMed]

172. Kyuno, D.; Zhao, K.; Schnölzer, M.; Provaznik, J.; Hackert, T.; Zöller, M. Claudin7-dependent exosome-promoted reprogramming of nonmetastasizing tumor cells. Int. J. Cancer 2019, 145, 2182-2200. [CrossRef] [PubMed]

173. Capello, M.; Vykoukal, J.V.; Katayama, H.; Bantis, L.E.; Wang, H.; Kundnani, D.L.; Aguilar-Bonavides, C.; Aguilar, M.; Tripathi, S.C.; Dhillon, D.S.; et al. Exosomes harbor B cell targets in pancreatic adenocarcinoma and exert decoy function against complement-mediated cytotoxicity. Nat. Commun. 2019, 10,1-13. [CrossRef]

174. Shang, D.; Xie, C.; Hu, J.; Tan, J.; Yuan, Y.; Liu, Z.; Yang, Z. Pancreatic cancer cell-derived exosomal microRNA-27a promotes angiogenesis of human microvascular endothelial cells in pancreatic cancer via BTG2. J. Cell. Mol. Med. 2019, 24, 588-604. [CrossRef] [PubMed]

175. Li, J.; Li, Z.; Jiang, P.; Peng, M.; Zhang, X.; Chen, K.; Liu, H.; Bi, H.; Liu, X.; Li, X. Circular RNA IARS (circ-IARS) secreted by pancreatic cancer cells and located within exosomes regulates endothelial monolayer permeability to promote tumor metastasis. J. Exp. Clin. Cancer Res. 2018, 37, 1-16. [CrossRef]

176. Gutkin, A.; Uziel, O.; Beery, E.; Nordenberg, J.; Pinchasi, M.; Goldvaser, H.; Henick, S.; Goldberg, M.; Lahav, M. Tumor cells derived exosomes contain hTERT mRNA and transform nonmalignant fibroblasts into telomerase positive cells. Oncotarget 2016, 7, 59173-59188. [CrossRef]

177. Wang, Z.; Von Au, A.; Schnölzer, M.; Hackert, T.; Zöller, M. CD44v6-competent tumor exosomes promote motility, invasion and cancer-initiating cell marker expression in pancreatic and colorectal cancer cells. Oncotarget 2016, 7, 55409-55436. [CrossRef]

178. Kugel, S.; Sebastian, C.; Fitamant, J.; Ross, K.N.; Saha, S.K.; Jain, E.; Gladden, A.; Arora, K.S.; Kato, Y.; Rivera, M.N.; et al. SIRT6 Suppresses Pancreatic Cancer through Control of Lin28b. Cell 2016, 165, 1401-1415. [CrossRef]

179. Shin, S.J.; Smith, J.A.; Rezniczek, G.A.; Pan, S.; Chen, R.; Brentnall, T.A.; Wiche, G.; Kelly, K.A. Unexpected gain of function for the scaffolding protein plectin due to mislocalization in pancreatic cancer. Proc. Natl. Acad. Sci. USA 2013, 110, 19414-19419. [CrossRef]

180. Jin, H.; Liu, P.; Wu, Y.; Meng, X.; Wu, M.; Han, J.; Tan, X. Exosomal zinc transporter ZIP4 promotes cancer growth and is a novel diagnostic biomarker for pancreatic cancer. Cancer Sci. 2018, 109, 2946-2956. [CrossRef]

181. Li, Z.; Tao, Y.; Wang, X.; Jiang, P.; Li, J.; Peng, M.; Zhang, X.; Chen, K.; Liu, H.; Zhen, P.; et al. Tumor-Secreted Exosomal miR-222 Promotes Tumor Progression via Regulating P27 Expression and Re-Localization in Pancreatic Cancer. Cell. Physiol. Biochem. 2018, 51, 610-629. [CrossRef]

182. Yu, Z.; Zhao, S.; Wang, L.; Wang, J.; Zhou, J. miRNA-339-5p Plays an Important Role in Invasion and Migration of Pancreatic Cancer Cells. Med. Sci. Monit. 2019, 25, 7509-7517. [CrossRef]

183. Li, Z.; Yanfang, W.; Li, J.; Jiang, P.; Peng, T.; Chen, K.; Zhao, X.; Zhang, Y.; Zhen, P.; Zhu, J.; et al. Tumor-released exosomal circular RNA PDE8A promotes invasive growth via the miR-338/MACC1/MET pathway in pancreatic cancer. Cancer Lett. 2018, 432, 237-250. [CrossRef] [PubMed]

184. Chen, D.; Wu, X.; Xia, M.; Wu, F.; Ding, J.; Jiao, Y.; Zhan, Q.; An, F. Upregulated exosomic miR-23b-3p plays regulatory roles in the progression of pancreatic cancer. Oncol. Rep. 2017, 38, 2182-2188. [CrossRef] [PubMed]

185. Wu, M.; Tan, X.; Liu, P.; Yang, Y.; Huang, Y.; Liu, X.; Meng, X.; Yu, B.; Wu, Y.; Jin, H. Role of exosomal microRNA-125b-5p in conferring the metastatic phenotype among pancreatic cancer cells with different potential of metastasis. Life Sci. 2020, 255, 117857. [CrossRef] [PubMed]

186. Li, Z.; Jiang, P.; Li, J.; Peng, M.; Zhao, X.; Zhang, X.; Chen, K.; Zhang, Y.; Liu, H.; Gan, L.; et al. Tumor-derived exosomal lnc-Sox2ot promotes EMT and stemness by acting as a ceRNA in pancreatic ductal adenocarcinoma. Oncogene 2018, 37, 3822-3838. [CrossRef]

187. Leca, J.; Martinez, S.; Lac, S.; Nigri, J.; Secq, V.; Rubis, M.; Bressy, C.; Sergé, A.; Lavaut, M.-N.; Dusetti, N.; et al. Cancerassociated fibroblast-derived annexin A6+ extracellular vesicles support pancreatic cancer aggressiveness. J. Clin. Investig. 2016, 126, 4140-4156. [CrossRef]

188. Richards, K.E.; Zeleniak, A.E.; Fishel, M.L.; Wu, J.; Littlepage, L.E.; Hill, R. Cancer-associated fibroblast exosomes regulate survival and proliferation of pancreatic cancer cells. Oncogene 2017, 36, 1770-1778. [CrossRef] 
189. Fang, Y.; Zhou, W.; Rong, Y.; Kuang, T.; Xu, X.; Wu, W.; Wang, D.; Lou, W. Exosomal miRNA-106b from cancer-associated fibroblast promotes gemcitabine resistance in pancreatic cancer. Exp. Cell Res. 2019, 383, 111543. [CrossRef] [PubMed]

190. Fan, J.; Wei, Q.; Koay, E.J.; Liu, Y.; Ning, B.; Bernard, P.W.; Zhang, N.; Han, H.; Katz, M.H.; Zhao, Z.; et al. Chemoresistance Transmission via Exosome-Mediated EphA2 Transfer in Pancreatic Cancer. Theranostics 2018, 8, 5986-5994. [CrossRef] [PubMed]

191. Melo, S.; Luecke, L.B.; Kahlert, C.; Fernandez, A.F.; Gammon, S.T.; Kaye, J.; LeBleu, V.S.; Mittendorf, E.A.; Weitz, J.; Rahbari, N.; et al. Glypican-1 identifies cancer exosomes and detects early pancreatic cancer. Nature 2015, 523, 177-182. [CrossRef] [PubMed]

192. Buscail, E.; Chauvet, A.; Quincy, P.; Degrandi, O.; Buscail, C.; Lamrissi, I.; Moranvillier, I.; Caumont, C.; Verdon, S.; Brisson, A.; et al. CD63-GPC1-Positive Exosomes Coupled with CA19-9 Offer Good Diagnostic Potential for Resectable Pancreatic Ductal Adenocarcinoma. Transl. Oncol. 2019, 12, 1395-1403. [CrossRef]

193. Frampton, A.E.; Prado, M.M.; López-Jiménez, E.; Fajardo-Puerta, A.B.; Jawad, Z.A.R.; Lawton, P.; Giovannetti, E.; Habib, N.A.; Castellano, L.; Stebbing, J.; et al. Glypican-1 is enriched in circulating-exosomes in pancreatic cancer and correlates with tumor burden. Oncotarget 2018, 9, 19006-19013. [CrossRef] [PubMed]

194. Yang, K.S.; Im, H.; Hong, S.; Pergolini, I.; del Castillo, A.F.; Wang, R.; Clardy, S.; Huang, C.-H.; Pille, C.; Ferrone, S.; et al Multiparametric plasma EV profiling facilitates diagnosis of pancreatic malignancy. Sci. Transl. Med. 2017, 9, eaal3226. [CrossRef] [PubMed]

195. Flammang, I.; Reese, M.; Yang, Z.; Eble, J.A.; Dhayat, S.A. Tumor-Suppressive miR-192-5p Has Prognostic Value in Pancreatic Ductal Adenocarcinoma. Cancers 2020, 12, 1693. [CrossRef]

196. Zou, X.; Wei, J.; Huang, Z.; Zhou, X.; Lu, Z.; Zhu, W.; Miao, Y. Identification of a six-miRNA panel in serum benefiting pancreatic cancer diagnosis. Cancer Med. 2019, 8, 2810-2822. [CrossRef]

197. Lai, X.; Wang, M.; McElyea, S.D.; Sherman, S.; House, M.; Korc, M. A microRNA signature in circulating exosomes is superior to exosomal glypican-1 levels for diagnosing pancreatic cancer. Cancer Lett. 2017, 393, 86-93. [CrossRef]

198. Que, R.; Ding, G.; Chen, J.; Cao, L. Analysis of serum exosomal microRNAs and clinicopathologic features of patients with pancreatic adenocarcinoma. World J. Surg. Oncol. 2013, 11, 219. [CrossRef] [PubMed]

199. Kawamura, S.; Iinuma, H.; Wada, K.; Takahashi, K.; Minezaki, S.; Kainuma, M.; Shibuya, M.; Miura, F.; Sano, K. Exosomeencapsulated microRNA-4525, microRNA-451a and microRNA-21 in portal vein blood is a high-sensitive liquid biomarker for the selection of high-risk pancreatic ductal adenocarcinoma patients. J Hepatobiliary Pancreat. Sci. 2019, 26, 63-72. [CrossRef]

200. Nakamura, S.; Sadakari, Y.; Ohtsuka, T.; Okayama, T.; Nakashima, Y.; Gotoh, Y.; Saeki, K.; Mori, Y.; Nakata, K.; Miyasaka, Y.; et al. Pancreatic Juice Exosomal MicroRNAs as Biomarkers for Detection of Pancreatic Ductal Adenocarcinoma. Ann. Surg. Oncol. 2019, 26, 2104-2111. [CrossRef]

201. Feng, Y.-H.; Tsao, C.-J. Emerging role of microRNA-21 in cancer. Biomed. Rep. 2016, 5, 395-402. [CrossRef]

202. Lux, A.; Kahlert, C.; Grützmann, R.; Pilarsky, C. c-Met and PD-L1 on Circulating Exosomes as Diagnostic and Prognostic Markers for Pancreatic Cancer. Int. J. Mol. Sci. 2019, 20, 3305. [CrossRef]

203. Giampieri, R.; Piva, F.; Occhipinti, G.; Bittoni, A.; Righetti, A.; Pagliaretta, S.; Murrone, A.; Bianchi, F.; Amantini, C.; Giulietti, M.; et al. Clinical impact of different exosomes' protein expression in pancreatic ductal carcinoma patients treated with standard first line palliative chemotherapy. PLoS ONE 2019, 14, e0215990. [CrossRef] [PubMed]

204. Lane, J.S.; Von Hoff, D.; Cridebring, D.; Goel, A. Extracellular Vesicles in Diagnosis and Treatment of Pancreatic Cancer: Current State and Future Perspectives. Cancers 2020, 12, 1530. [CrossRef] [PubMed]

205. Castillo, J.; Bernard, V.; San Lucas, F.A.; Allenson, K.; Capello, M.; Kim, D.U.; Gascoyne, P.; Mulu, F.C.; Stephens, B.M.; Huang, J.; et al. Surfaceome profiling enables isolation of cancer-specific exosomal cargo in liquid biopsies from pancreatic cancer patients. Ann. Oncol. 2017, 29, 223-229. [CrossRef] [PubMed]

206. Liu, J.; Gao, J.; Du, Y.; Li, Z.; Ren, Y.; Gu, J.; Wang, X.; Gong, Y.; Wang, W.; Kong, X. Combination of plasma microRNAs with serum CA19-9 for early detection of pancreatic cancer. Int. J. Cancer 2011, 131, 683-691. [CrossRef] [PubMed]

207. Liu, R.; Chen, X.; Du, Y.; Yao, W.; Shen, L.; Wang, C.; Hu, Z.; Zhuang, R.; Ning, G.; Zhang, C.; et al. Serum MicroRNA Expression Profile as a Biomarker in the Diagnosis and Prognosis of Pancreatic Cancer. Clin. Chem. 2012, 58, 610-618. [CrossRef]

208. Li, A.; Yu, J.; Kim, H.; Wolfgang, C.L.; Canto, M.I.; Hruban, R.H.; Goggins, M. MicroRNA Array Analysis Finds Elevated Serum miR-1290 Accurately Distinguishes Patients with Low-Stage Pancreatic Cancer from Healthy and Disease Controls. Clin. Cancer Res. 2013, 19, 3600-3610. [CrossRef]

209. Joshi, G.K.; Deitz-McElyea, S.; Liyanage, T.; Lawrence, K.; Mali, S.; Sardar, R.; Korc, M. Label-Free Nanoplasmonic-Based Short Noncoding RNA Sensing at Attomolar Concentrations Allows for Quantitative and Highly Specific Assay of MicroRNA-10b in Biological Fluids and Circulating Exosomes. ACS Nano 2015, 9, 11075-11089. [CrossRef]

210. Xu, Y.-F.; Hannafon, B.N.; Zhao, Y.D.; Postier, R.G.; Ding, W.-Q. Plasma exosome miR-196a and miR-1246 are potential indicators of localized pancreatic cancer. Oncotarget 2017, 8, 77028-77040. [CrossRef]

211. Zhou, X.; Lu, Z.; Wang, T.; Huang, Z.; Zhu, W.; Miao, Y. Plasma miRNAs in diagnosis and prognosis of pancreatic cancer: A miRNA expression analysis. Gene 2018, 673, 181-193. [CrossRef]

212. Wang, C.; Wang, J.; Cui, W.; Liu, Y.; Zhou, H.; Wang, Y.; Chen, X.; Chen, X.; Wang, Z. Serum Exosomal miRNA-1226 as Potential Biomarker of Pancreatic Ductal Adenocarcinoma. OncoTargets Ther. 2021, 14, 1441-1451. [CrossRef] [PubMed]

213. Madhavan, B.; Yue, S.; Galli, U.; Rana, S.; Gross, W.; Müller, M.; Giese, N.A.; Kalthoff, H.; Becker, T.; Büchler, M.W.; et al Combined evaluation of a panel of protein and miRNA serum-exosome biomarkers for pancreatic cancer diagnosis increases sensitivity and specificity. Int. J. Cancer 2014, 136, 2616-2627. [CrossRef] [PubMed] 
214. Lennon, K.M.; Wakefield, D.L.; Maddox, A.L.; Brehove, M.S.; Willner, A.N.; Garcia-Mansfield, K.; Meechoovet, B.; Reiman, R.; Hutchins, E.; Miller, M.M.; et al. Single molecule characterization of individual extracellular vesicles from pancreatic cancer. J. Extracell. Vesicles 2019, 8, 1685634. [CrossRef] [PubMed]

215. Kimura, H.; Yamamoto, H.; Harada, T.; Fumoto, K.; Osugi, Y.; Sada, R.; Maehara, N.; Hikita, H.; Mori, S.; Eguchi, H.; et al. CKAP4, a DKK1 Receptor, Is a Biomarker in Exosomes Derived from Pancreatic Cancer and a Molecular Target for Therapy. Clin. Cancer Res. 2019, 25, 1936-1947. [CrossRef] [PubMed]

216. Xie, Z.; Gao, Y.; Ho, C.; Li, L.; Jin, C.; Wang, X.; Zou, C.; Mao, Y.; Wang, X.; Li, Q.; et al. Exosome-delivered CD44v6/C1QBP complex drives pancreatic cancer liver metastasis by promoting fibrotic liver microenvironment. Gut 2021. [CrossRef] [PubMed]

217. Kamerkar, S.; LeBleu, V.S.; Sugimoto, H.; Yang, S.; Ruivo, C.F.; Melo, S.A.; Lee, J.J.; Kalluri, R. Exosomes facilitate therapeutic targeting of oncogenic KRAS in pancreatic cancer. Nature 2017, 546, 498-503. [CrossRef]

218. Pascucci, L.; Coccè, V.; Bonomi, A.; Ami, D.; Ceccarelli, P.; Ciusani, E.; Viganò, L.; Locatelli, A.; Sisto, F.; Doglia, S.M.; et al. Paclitaxel is incorporated by mesenchymal stromal cells and released in exosomes that inhibit in vitro tumor growth: A new approach for drug delivery. J. Control. Release 2014, 192, 262-270. [CrossRef]

219. Zhou, W.; Zhou, Y.; Chen, X.; Ning, T.; Chen, H.; Guo, Q.; Zhang, Y.; Liu, P.; Zhang, Y.; Li, C.; et al. Pancreatic cancer-targeting exosomes for enhancing immunotherapy and reprogramming tumor microenvironment. Biomaterials 2020, 268, 120546. [CrossRef]

220. Tian, Y.; Li, S.; Song, J.; Ji, T.; Zhu, M.; Anderson, G.J.; Wei, J.; Nie, G. A doxorubicin delivery platform using engineered natural membrane vesicle exosomes for targeted tumor therapy. Biomaterials 2013, 35, 2383-2390. [CrossRef]

221. Barile, L.; Vassalli, G. Exosomes: Therapy delivery tools and biomarkers of diseases. Pharmacol. Ther. 2017, 174, 63-78. [CrossRef] [PubMed]

222. Li, Y.-J.; Wu, J.-Y.; Liu, J.; Xu, W.; Qiu, X.; Huang, S.; Hu, X.-B.; Xiang, D.-X. Artificial exosomes for translational nanomedicine. J. Nanobiotechnol. 2021, 19, 242. [CrossRef] [PubMed] 